B YHRTCAN SOCIRTY OF CIVIL WNGINEBRS.

\title{
PLANT AND MATERIAL OF THE PANAMA CANAL
}

WLLIIAM PLUMB WILLIAMS, JUn, Am, Soc. C. E. 
PFOPERTY GF

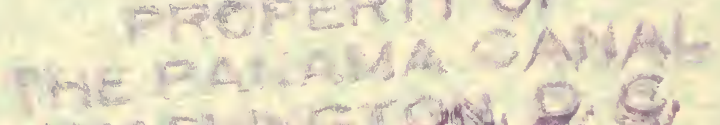

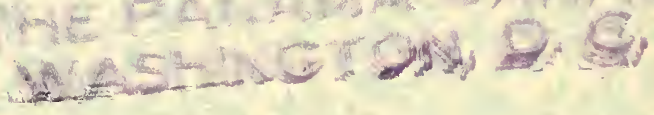




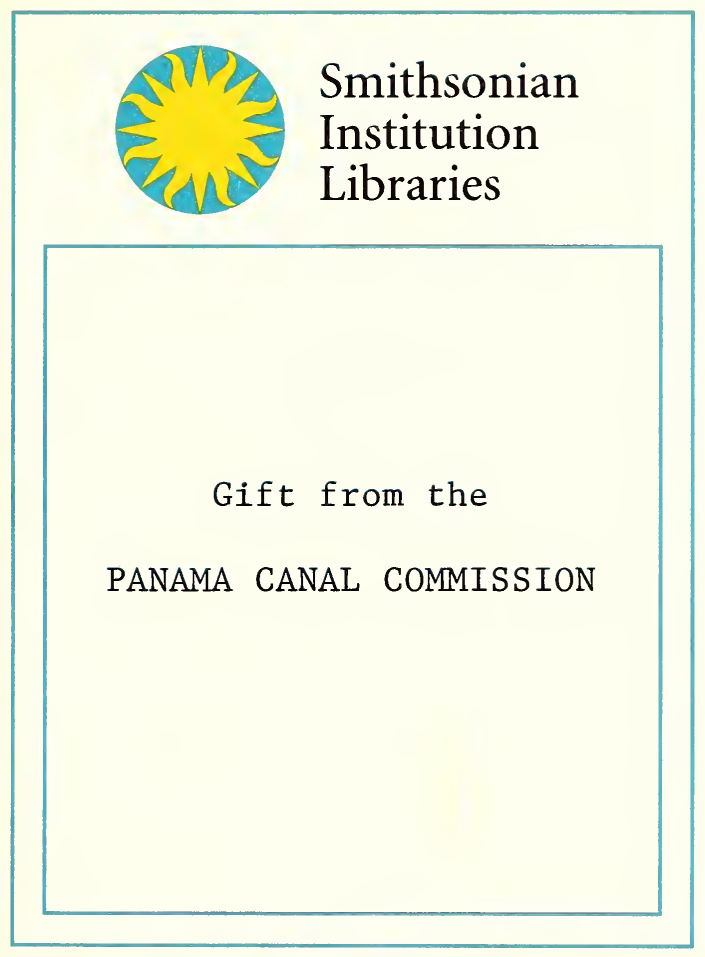





AMERICAN SOCIETY OF CIVIL ENGINEERS.

PLANT AND MATERIAL OF THE PANAMA CANAL.

$\mathbf{B Y}$

WILliaM PLUMB WILliams, Jun. Am. Soc. C. E. 



\title{
AMERICAN SOCIETY OF CIVIL ENGINEERS.
}

\author{
INSTITUTED 1852 .
}

\section{TRANSA CTIONS.}

NorE.-This Society is not responsible, as a body, for the facts and opinions_advanced in any of its publications.

400.

(Vol. XIX.-December, 1888.)

\section{PLANT AND MATERIAI, OF THE PANAMA} CANAL.

By William Plumb Williams, Jun. Am. Soc. C. E.

Read July 2D, 1888.

The engineering world has been presented from time to time during the last eight years with accounts of the financial conditions and probable completion of the Panama Canal. These accounts have been in a large measure circulated in America for a desired effect by friends of the Canal Company, while other reports prejudicial to the Company have arisen from employees returning to this country out of health, or from disappointed contractors.

While on the Isthmus in the spring of 1888 I was afforded an excellent opportunity of making a thorough investigation of the whole work, and I think it interesting enough to American engineers to describe the methods of work and the plant and machinery employed in accomplishing the largest task of modern times.

A number of accounts of this work have been given by persons who gained their ideas from the windows of a passing railway train, and by hurried visits here and there to the different sections contiguous to the line of the Panama Railroad. This is so unsatisfactory a manner to see all systems of work, that I determined to go over the entire route, commencing 
at Colon, by steam launch up the canal 15 kilometers, which portion is dredged 15 feet in depth, and then continuing the journey on different days by foot and horseback until I reached La Boca, the Panama end of the line.

In five weeks I traveled over the axial line of canal from Aspinwall to Panama, making a slow and careful examination. In many cases I secured statements from engineers of the Panama Canal Company, enginears of contractors, contractors, foremen and intelligent workmen, and in order to base an accurate opinion, $I$ have seen all plant individually. It might be well to state that an American engineer need not go to Panama to learn how to execute effective and economical work, and it was most gratifying to contrast the expensive, slow and cumbersome methods employed by the French contractors with the lighter, more rapid and economical plant of American manufacture, used by contractors in the United States.

All plant on the Panama Canal is owned by the Canal Company, being leased to the different contractors along the line for 8 per cent. a year on the value of the machinery. This system has been expensive to the Company, as contractors not owning the machines would work them daily up to their maximum capacity, spending little or no time in repairs of minor working parts. These machines, from this want of care, would soon break down, and would be sidetracked, the contractor making a requisition for a new machine to continue the work. I saw hundreds of expensive excavators, rock drills, cranes, locomotives and hoisting engines side-tracked and condemned, only lacking a casting here and there to place the machine in working condition, but through negligence of the workmen rendered useless.

The atmosphere of the whole work is indicative of extravagance, the contractor regarding the Canal Company as a bank of inexhaustible. supply, to be drawn upon at all times, and in some cases the claims for demurrages, breakages and losses made by the contractor are unfair, but are paid even though resulting in large loss to the Canal Company. In short, the climate is deadly, the contractor taking his life in his own hands when he goes there, and it is a question of making the largest amount of money in the shortest possible time in order to leave the country and enjoy the profits in a more healthful climate.

During the primary stages of the work the Canal Company placed orders for plant with the different foundries throughout France and 


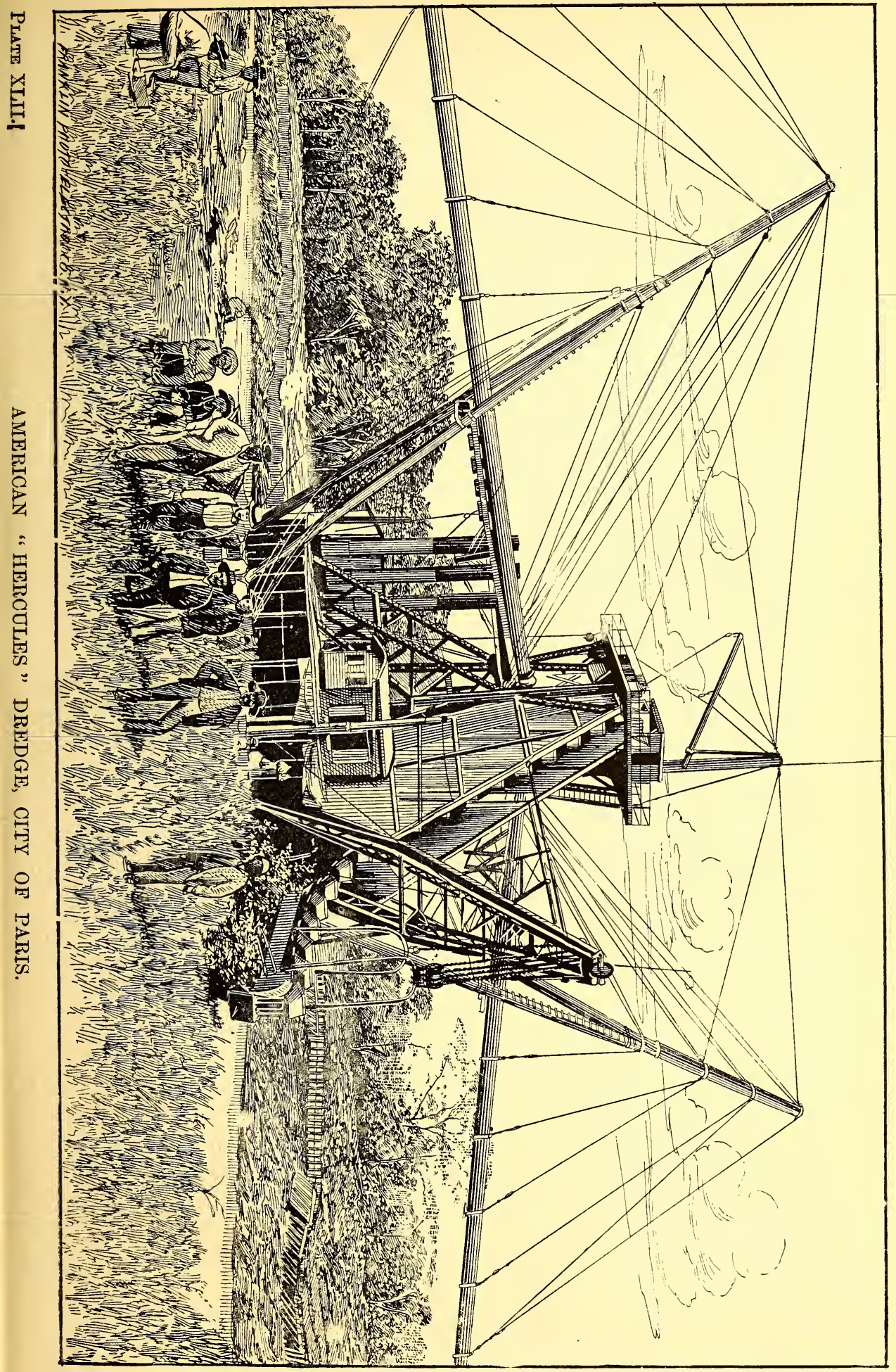



Belgium, which, being overtaxed, could not supply the machines fast enough. Consequently, the Canal Company made contracts with the several firms on the Isthmus to supply their own plant, to be bought by the Canal Company, paying the contractors 15 per cent. commission for their trouble.

This will account for the enormous amount of material on hand, such as hoisting engines, locomotives, cranes, dump cars, steel rails and dredges. This plant was purchased in quantities largely in excess of the amount necessary for constructing a sea-level canal, the contractors profiting by the excess of orders in their commissions; but now that the work is diminished by adopting a lock system, this large amount of plant will rapidly deteriorate by the action of the climate and be rendered useless. There are many varieties of the different kinds of machinery in use, but I have restricted my mention to those which have done the most satisfactory and economical work, in some cases describing plant which has not been intelligently used by the contractors.

The dredges in use are as follows:

American Hercules dredges, French dredges, Belgian dredges and Scotch dredges.

The Amertoan Hercules type (Plates XLII and XLIII) is operated by the American Contracting and Dredging Company, of New York, and their work all along the line on the Aspinwall side of the canal shows for itself as an evidence of what American contractors can accomplish in a tropical climate by their great activity and energy. I might also state that they are the only firm of contractors who have successfully carried out their work on time.

Their plant is as follows:

1. Count de Lesseps, Low tower................All wood.

2. Nathan Appleton,

3. M. A. Slaven,

4. H. B. Slavien,

5. Dingler,

"

.............. "

"

High tower.............. "

6. City of Paris, High iron tower...........Wooden hull.

7. City of New York,

I find that this company has done good work by employing intelligent and skilled labor, mostly American, Irish 'and Swedish, housing and feeding their complement of men, and by attention to their welfare. The organization has been thorough, and the bonus system, by which the Captain and crew of the dredge are paid a certain amount of money pro 
rata for having exceeded the average amount of work in any month, instills a high degree of ambition amongst the force. As to the amount of work done by the dredges I will mention the City of New York, at work at kilometer 14, deepening the channel of the canal from 15 feet. 'This machine was running nineteen to twenty-one buckets per minute, threefourths full, three buckets to the cubic meter. The expansion of material in buckets was $30 \mathrm{per}$ cent., occupying more volume in the buckets than in bank. I estimated in twenty-four hours' work it would accomplish 4800 cubic meters. There are from forty-five to fifty-five men on these machines, distributed as follows:

1 Captain.................. \$300 00 per month.

3 Assistant engineers............. 15000 "6

3 Firemen...................... 7000 "

3 Oilers..................... 5000 "

3 Diggers................... 6500 "

3 Gypseymen..................... 6500

1 Steward and three cooks.......... 7500 "

6 Waiter boys.. ................. 3000 "

Seamen.................. 5000 "

These men are divided into three watches of eight hours each, the machines working night and day, only stopping to repair machinery. Sunday is usually occupied in replacing any worn-out material, replacing links, and anticipating any breakages in upper tumbler bars, boiler tubes, spud-gear, etc. From reliable records I find the average work to be relied upon is 100000 cubic yards per month. The Dingler has excavated 237000 cubic yards in one month, but it was in redredging material which had slid back into the canal, which was well lubricated and free from such obstructions as stumps and coral rock, allowing the machine to run at a higher speed, fearing nothing from disabling machinery or stoppages of flow of material through pipes from obstructions. I also find that the vibrations of the chain of buckets and links is reduced to a minimum when excavating in material not tenacious, allowing buckets to revolve twenty-five to thirty per minute.

The dredges of iron-tower construction have done satisfactory work, and are lighter in tonnage and of less draught than those of wooden structure, and much more stiff.

The first wooden dredges sent down to the Isthmus were not of the best quality. The Appleton was built in Philadelphia, and has done good work and been subjected to strains of rock and coral dredging, but her tower and hull are giving way more than is warranted had proper material been originally used. The tower being subject to the maximum 


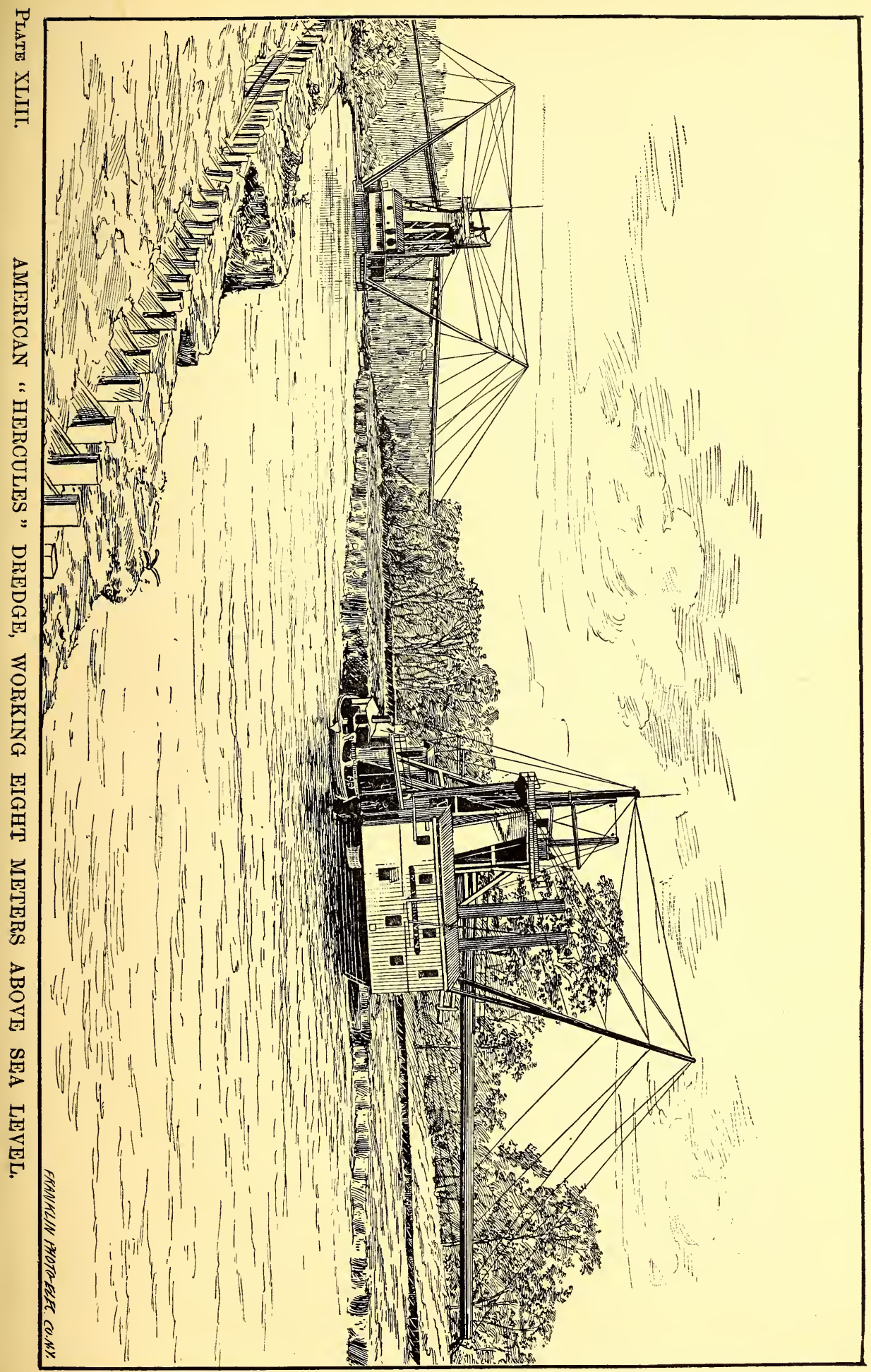


| 
strains, it was deemed advisable to build a machine with an iron tower, and in the City of New York and City of Paris I find a most admirable style of construction, the machinery running more smoothly and with less vibration than in the wooden tower. In the wooden towers packing pieces have been resorted to in order to build up solidly all spaces in the upper tower where shafting causes heavy strains and vibrations. Although perfect in work at first, yet from the elasticity of the wood and through friction the joints increased in size and the whole packing became loosened. In order to gain the immense strength necessary at so great height, 75 feet from the deck, the timbers are of large size, which increases the original cost and increases the tonnage proportionately. Sampson posts, bracing timbers, and packing pieces must be used as stiffeners. In the iron towers less total weight of material is used, reducing depth of flotation. The tower must be built to resist the strain of belt, producing a pulling strain from forward tending aft, and also the thrust of ladder, resolved into a horizontal thrust at tower and also tending aft. Thus these strains are all in the same direction and transmitted from strong tower to keelsons and distributed throughout the hull. The method of raising and lowering the ladder and the raising and lowering of the spuds may be improved by adopting hydraulic means. The spuds used as an axis upon which the dredge revolves are more effective than the control of movements of dredge by fore and aft guys as in Belgian, French and Scotch dredges, as rigidly holding the center of dredge and allowing revolution through a true arc, obviating the ridges which are caused by unequal work on the furrows in the other systems. The cost of the Hercules type has varied in the several machines from $\$ 100000$ to $\$ 120000$ complete at New York, tonnage on first machines being $\$ 5000$ to Colon and as low as $\$ 3250$ on the last machine. The same dredges could be built at the present time 15 per cent. cheaper and in a firstclass manner. The Dredging Company have improved their machines from time to time, and even now, in the event of building a new dredge, could embody valuable improvements. I might say that the type of endless-chain-of-bucket dredges has been in use many years, and the Hercules type may be built at a royalty of $\$ 5000$ upon each machine, to be paid to the holders of the patent. I would especially note the importance of this type, as in using the high tower and long pipe of discharge, the capacity of work of the dredge is independent of the elements or human work other than on board of the machine. In other systems 
emptying into clapets or discharging through pipes supported on pontoons, unavoidable delays arise from non-unity of action, delays in dumping clapets, and serious and unavoidable delays where a number of details of work must be successfully carried out to aid the pe:formance of work of the parent machine. With the Hercules type this is illustrated, as night and day the machine is worked, the captain having a complete control of his machine and not being dependent on crews of men not under his supervision. This is also forcibly illustrated in visiting Belgian, Scotch and French dredges, machines capable of doing fair work, yet handicapped by minor details of superintendence and unsatisfactory work of their auxiliaries. The Hercules type consumes about ten tons of coal per day, and this item is a large one, considering the cost of transportation and trans-shipment of coal, and I would recommend, in future machines, that patent bridge walls and improved boiler construction be examined with reference to using less coal by more economical combustion of fuel. The buckets of the Hercules are a serious objection to their doing effective work in clay or tenacious material, as, on account of prismoidal form, they afford means of material adhering to the corners and bottom of bucket. I made visits to the Dingler, Appleton, M. A. Slaven, H. B. Slaven, City of New York and City of Paris, timing all work, noting quality of excavation in soft, sticky clay, hard clay, dredging material and sand, which I would estimate as follows:

Soft, sticky clay, buckets not fully emptying at up-

$$
\begin{aligned}
& \text { Cubic Yards } \\
& \text { per day. }
\end{aligned}
$$

per tumbler.......................3000 to 4000

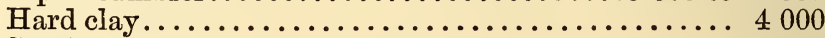

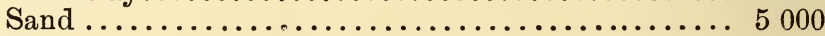

Allowing one day of each week for repairs of machinery, and all days regarded as twenty-four working hours. The estimate of cost of work must embrace the following items : Cost of dredge, towage and insurance to Colon; cost of erection and placing all machinery in working order; building and equipping a machine shop; supplying duplicate machinery at short notice in case of breakage; maintenance of crew; hospital service; cost of New York office and Colon office; erecting fence on banks to prevent sliding of material back into canal ; leveling off tops of banks under discharge pipes when too high. In the first contract of the American Contracting and Dredging Company the price was thirty-five cents per cubic meter, and from estimates given me by 
the company's engineer I may safely say that there was fifty per cent. profit in the work at that price. I have made investigation into all details of work done by this company, they having encountered difficult problems, dredging in low, marshy grounds where sliding of whole surface of marsh into the channel caused many delays, and the dredging of materials 7 to 8 meters above water level by erecting a system of dams. Their work, although performed satisfactorily, and to the great astonishment of the Frenchmen, is only a fair example of what our American contracting firms can accomplish in a tropical climate. Practically the whole work of the Hercules dredge is controlled by one man, who is stationed on the bow of the machine. A system of wheels at his hand connects with the different engines, namely, raising and lowering the lever; controlling the main engine, and velocity of revolution of buckets; the gypsey engine working the side guys; the spuds also being raised and lowered by tackles on hoisting drums. The digger may, at a glance, take in the situation, and use his governing wheels accordingly. Referring to the machine shops at Gatun of the Dredging Company, I would say they are so constructed as to do ordinary repairs of machinery at the shortest possible notice, and this plant cannot be dwelt upon too strongly, as in a region of no foundries and machine shops, a duplication of the principal parts of machinery should be attended to and complete shops built to supply these parts. The question of time is a most important element, and sending to the States for any supplies should be anticipated before breakage should occur. The report circulated in New York that the Hercules type of machine could dredge 16000 cubic yards in one day of twenty-four hours arose as follows : at Gatun, in sandy and solt clay material, frequent sliding in the material occurred, so that the dredge was obliged to retreat to the rear and redredge the material. Material being soft and well lubricated, was easily attacked, allowing the buckets to revolve with a velocity of 25 or 30 per minute, without fear of breaking links by the vibratory movement occasioned by the upper tumbler, a square body going through an angle of 360 degrees. A word as to the preparation of land for dredges. The first contract for clearing and grubbing of right of way should be rigidly enforced, and all stumps, trees and obstructions removed from surface of ground, as these materials cause frequent delay in stopping up discharge pipes, although the buckets are powerful enough to disintegrate the mass. 
Scotch Dredges (See Plate XLIV), are self-propelling, having steamed out from Scotland to Colon and also to Panama, passing around the Horn. Their boilers are of 200 horse-power, and their horizontal engines communicate power to a crank-shaft on which is a sprocket wheel. The upper tumbler shaft has also a sprocket wheel, and an endless chain communicates from the lower to the upper shaft, transmitting the motion. In heavy work these teeth break at frequent intervals. The ladder is in one section, requiring large construction of parts to gain the required strength for a long member. If in two sections it might be lighter and require less power to raise and lower. This dredge is more adapted for deep sea work than attacking new banks; it discharges into clapets and is controlled by fore-and-aft guys and side guys wound on friction drums. Its draught is 7 to 8 feet, and it burns 6 tons of coal per twelve working hours. I visited three Scotch dredges in the Bay of Panama, but their work in discharging into clapets averaged only 200 yards per hour on account of encountering coral rock. In ordinary work they accomplish 2000 to 3000 cubic meters per day of twelve hours.

The French Dredge (See Plate XLV and XLVI), is the principal dredge in use along the line of the Panama Canal. There are different sizes, the one most in use being 100 feet long by 30 feet broad, and having a draught of 7 feet of water. The hulls and entire machine are constructed of iron, in sections, in France, shipped to Colon and transshipped at different points along the line where they are to be used. The cost is approximately $\$ 115000$ at Colon, not including cost of erection, which has been an expensive work at Panama, some engineers estimating the cost of erection at 35 per cent. on original value. The tower is quite low, the elevation of hopper below upper tumbler being only 20 feet above water level. The ladder is in one section, supported upon axis in tower, and varies in length to the use of dredge in attacking new banks, or in deepening channels. The buckets are of iron, wrought in one piece, the links being an integral part of the bucket, which I do not regard as an economical construction, or any stronger than if in a separate piece, (the Slaven bucket has links bolted to the flanges on the back, so that in case the link becomes much worn it may be easily replaced by a new link without necessitating loss of bucket, which may be in perfect order). The power is derived from a vertical engine having three pistons, which act directly upward on a crank shaft, which has a gear-wheel 


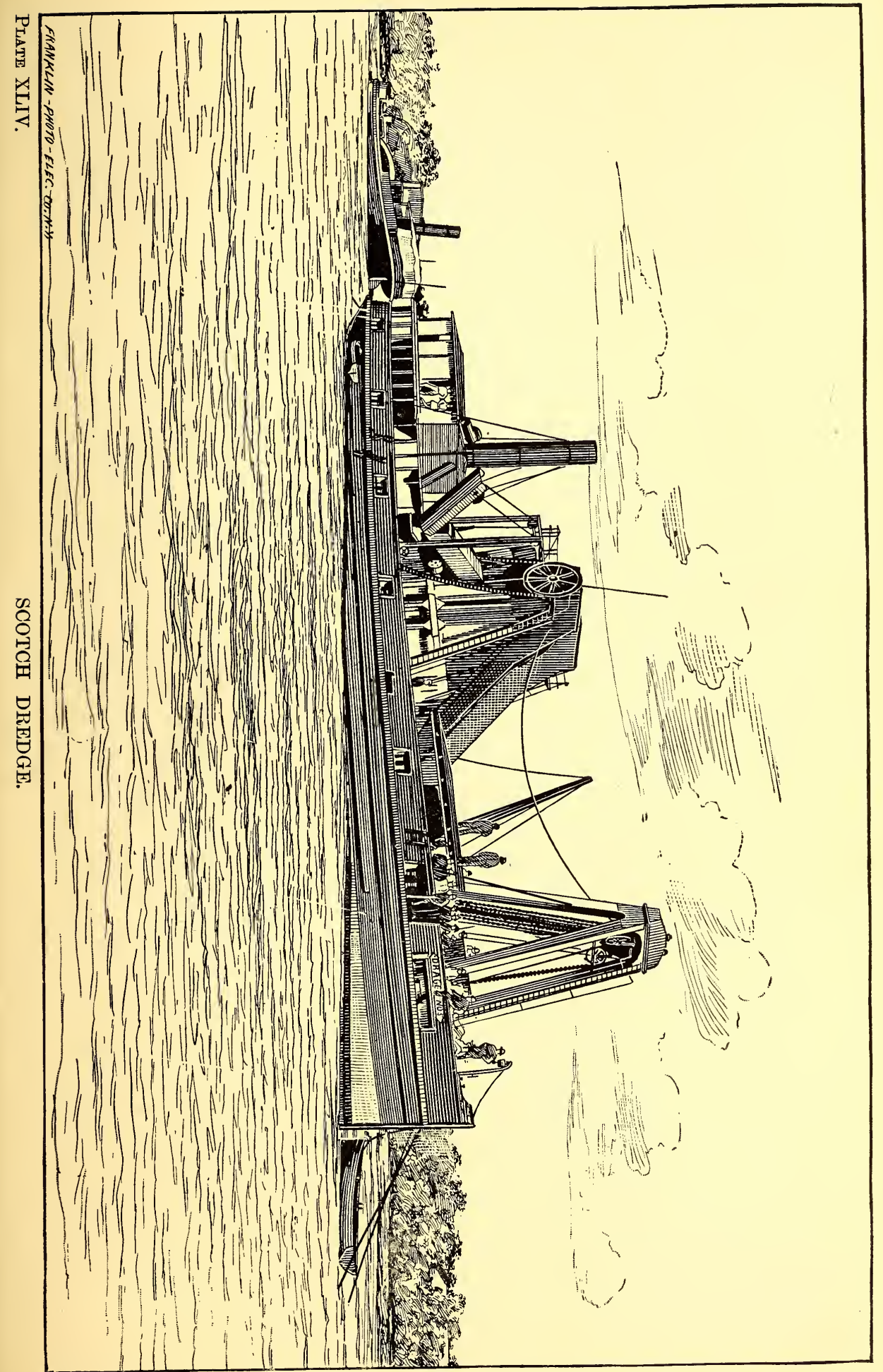



at either end, and large balance wheels. These gear-wheels connect through two other gear-wheels to the upper tumbler shaft, thus giving a positive power, and when machine is dredging in rock, no slipping occurs, as in a belt connection. The engines are $\mathbf{1 8 0}$ horse-power in this sized dredge, and it forms a most powerful machine, so that in attacking hard-pan or louse rock it receives such a force as to accomplish its work when buckets and links do not break. In ordinary work in sand, gravel, clay and loose material a positive force is not necessary, as in rock work. The large belt from a horizontal engine connecting with a gear attachment fitted with a tightener pulley, increasing or diminishing the tension, has given good satisfaction, and controls the movements, except in rock work.

The dimensions of a French dredge of large type are as follows: Length, 120 feet; breadth, 28 feet; depth, 10 feet; draught, 7 feet; depth of working, 28 feet ; sheer fore and aft, 10 inches ; rise of deck, 6 inches; height of discharge above water-line, 20 feet; height of top tumbler above water-line, 26 feet 6 inches; width of bucket well, 5 feet 3 inches ; frames, 4 inches by 3 inches by $\frac{3}{8}$ inch, 2 feet apart, with reverse angle irons 3 inches by 3 inches by $\frac{3}{8}$ inch, in alternate frames ; plating of bottom and bilges, near well, ${ }_{1}^{T} 6$ inch ; plating otherwise, $\frac{3}{8}$ inch ; plating of sides, $\frac{3}{8}$ inch ; plating of well, $\frac{3}{8}$ inch ; deck beams, bulb iron, 8 inches by $\frac{3}{8}$ inch, with double angle irons $2 \frac{1}{2}$ inches by $2 \frac{1}{2}$ inches by $\frac{3}{8}$ inch ; floors, 12 inches by 4 inches ; angle irons, 3 by 3 by $\frac{3}{8}$ inches ; length of bucket ladder between centers, 64 feet 6 inches ; capacity of buckets, 16 cubic feet ; diameter of pins, $2 \frac{7}{8}$ inches ; high pressure cylinders, 17 inches diameter by 24 -inch stroke; low pressure cylinders, 31 inches diameter by 24 -inch stroke; air pump, 10 inches diameter by 15 -inch stroke; circulating pump, 10 inches diameter by 15-inch stroke ; boiler diameter, 10 feet 6 inches ; boiler length, 9 feet 6 inches; boiler heating surface, 900 square feet; boiler working pressure, 80 pounds per square inch ; cost at Colon, $\$ 115000$.

One of these machines of large type has done valuable work at the Mindi Cut, near Gatun, on the Panama Canal, in broken rock, stiff clay and hard-pan. The material excavated in buckets is carried up into a hopper, discharged with water, pumped up hydraulically sufficiently to discharge it into self-dumping steam clapets alongside. The capacity of these dredges is variable in the extreme, no one machine having done a large amount of satisfactory work. A fair estimate, where no demurrage 
occurs from want of sufficient clapets alongside to allow the dredge to steadily discharge through twelve working hours, is 200 to 250 yards per hour. At La Boca, in Panama Bay, a dredge of this type was running twenty buckets per minute-three buckets per cubic meter when full; these were half filled. Coal consumed was about 10 tons per day, and working a crew of twenty-six men, composed of sixteen sailors at $\$ 50$ per month and ten men in the Engineering Department, the cost of maintenance being $\$ 188$ per day, excluding breakages.' One most important objection to these machines is the number of skilled men necessary to work the machine satisfactorily. The captain or digger stands on the bow of the dredge and takes in the situation, communicating by word his orders to the individual engineers, one in charge of main engine, one in charge of gypsey engine, controlling the side guys ; another controls by engine the fore-and-aft guys, while another engineer controls the ladder, raising or lowering it when necessary. In one case in question these positions were filled by Jamaicans, Columbians, Greeks and Italians, no two men being of the same degree of intelligence, causing unnecessary delay from loss of time and non-unity of action; while by a system of levers on the bow, connecting with each engine, the digger would be able at a glance to control his machine as completely as an engineer of a locomotive.

I regard these dredges, with this improvement, able to do effective work, and with a high tower and long discharge pipes equal to the Hercules, as their engínes are well built, and with good use of power well applied, their ladder and buckets built stiffly, and strains well distributed through tower and hull. The system in all foreign styles of dredges of constructing the ladder in one section is more adapted to deep-water dredging than to attacking new banks, while the double ladder of the Hercules type will excavate higher banks with less power applied to raising or lowering the ladder. By the control of the dredge by fore-andaft guys and by side guys, the work is not as evenly executed as when the dredge revolves upon a central axis or spud, as in a machine digging through an arc of 45 degrees it necessitates the slacking off of both forward and after guys and of one side guy, and "taking up" the other side guy, and as this work is done by several men, and with no absolute precision of action, it is seldom that a dredge is moving to and fro in concentric furrows.

French Dredges are also in use where the power is applied through 


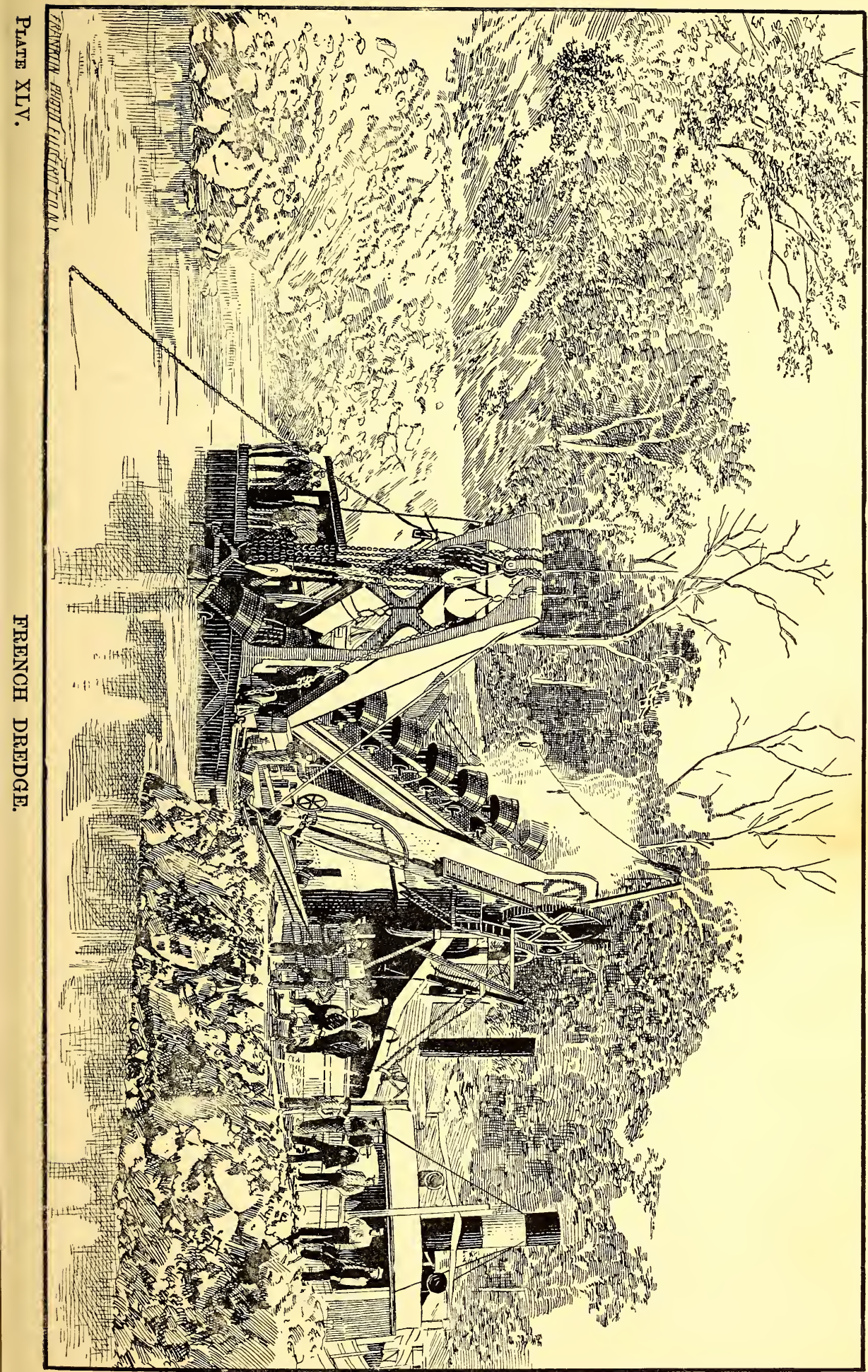



an endless chain fitting over sprocket wheels on the crank shaft and upper tumbler shaft. I find by this system that these teeth break frequently, and it would seem to be most advantageous to use in dredges designed for heavy work a vertical engine connecting directly to gear wheel gearing to upper tumbler shaft. A marked contrast is shown in all machines of foreign construction in being so much heavier in all details than American machines, and in the ladder two sections might have been used, each one having been built lighter and much more stiff than if building it in one section, thus necessitating a ponderous frame to resist buckling of the long length. I submit a record of work of the French dredge at La Boca, April 16th.

Character of material, obdurate clay 8 to 10 feet deep.

Clapet No. 5. Capacity 233 cubic meters, filled by dredge 1 hour.

\begin{tabular}{|c|c|c|c|c|c|}
\hline 8. & 66 & 66 & 66 & 66 & 45 minutes. \\
\hline 5. & "6 & "6 & "6 & ،6 & 55 \\
\hline 8. & 66 & 66 & 66 & 66 & 40 \\
\hline
\end{tabular}

Deducting sixty for amount of water in material and expansion, total 173 cubic meters; and I might add ten to fifteen minutes were lost each time a clapet came along side, made fast, and dredge commenced working. At Tavernilla, on April 17th, I examined a French dredge at work, attacking a bank 30 feet above water level. This dredge was of 200 horse-power, and by undermining the bank, causing it to fall into the bed of the stream, it was able to accomplish its work. The method of discharge was hydraulic, as follows: in the neck of the hopper two gratings were securely placed at right angles, making squares 2 inches each way. The material discharged from bucket and falling onto grating was broken up a certain amount by two 8-inch streams of water, pumped hydraulically and directed in their discharge into the hopper to strike the falling material, which became disintegrated when going through the grating. The material then flowed outboard into a closed box at the lower end of the hopper. A scow made fast alongside of the dredge was supplied with hoiler and horizontal engine, communicating motion to a centrifugal pump with 'a 14-inch pipe; a vacuum being formed, the disintegrated and lubricated material in the box at bottom of hopper was taken by suction through the pump, and forced through the corrugated iron discharge pipes, 14 inches in diameter, and supported on pontoons moored in mid-stream; then forced in this case over onto the shore and 
discharged 30 feet higher than the pump, which was 15 feet above water level, so the elevation of the discharge was 45 feet above water level, and 600 feet distant. They claim to be doing 1200 cubic meters per day, which was possible when not detained by obstructions. The objection to this system is, that by contact of material with blades of pump oftentime bolts, snags, stones and obstructions of all kinds large enough to go through grating lengthwise would break the blades of the pump. Again, the capacity of dredge running twenty buckets per minute, and discharging material into pipe, in order to work effectively, would require discharge pipe of 20 inches in diameter, instead of 14 inches, as usually 60 to 80 per cent. of diameter of full discharge pipe is water, and the remainder material. The system of pontoons employed for support of pipe was successful. Four cylindrical air-tight boilers were constructed of iron, each 5 feet long by 3 feet in diameter. They were floated horizontally in the water and connected rigidly side by side, by wooden braces, and the raft thus formed supported a vertical $X$ brace at each end of the pontoon. The discharge pipe was supported in the $Y$ of the brace. Between the pontoons was a flexible joint 3 feet long, formed as follows: A sleeve of leather was made, the same diameter as pipe; this leather was covered with strong copper wire cloth to make the joint more rigid, and the whole riveted at each end to flange of corrugated iron, of same size as discharging pipe, and this point was made fast as an intermediate, allowing flexibility. This form is not as expensive as ball and socket joint connection, and with leather of sufficient thickness will stand high pressure 100 to 120 pounds to the square inch.

Where action of dredges is dependent upon discharge through pipes supported upon pontoons, circumstances arise which will seriously impair a regular quantity of work. Pontoons must be controlled with guys and end of discharge pipe moved from place to place when bank arises from accumulation of discharge material. The discharge pipe must be lengthened or shortened, and transported forward or aft, as the dredge moves forward in her channel of work.

Hydraduic Dredging. - The method of hydraulic discharge in use at Tavernilla $I$ have described, and at the same place $I$ saw in process of construction an auxiliary to the French dredge. An iron barge 60 feet long by 35 feet broad contained in the stern three horizontal engines of large type, stroke 3 feet, diameter of piston 20 inches. The piston was 


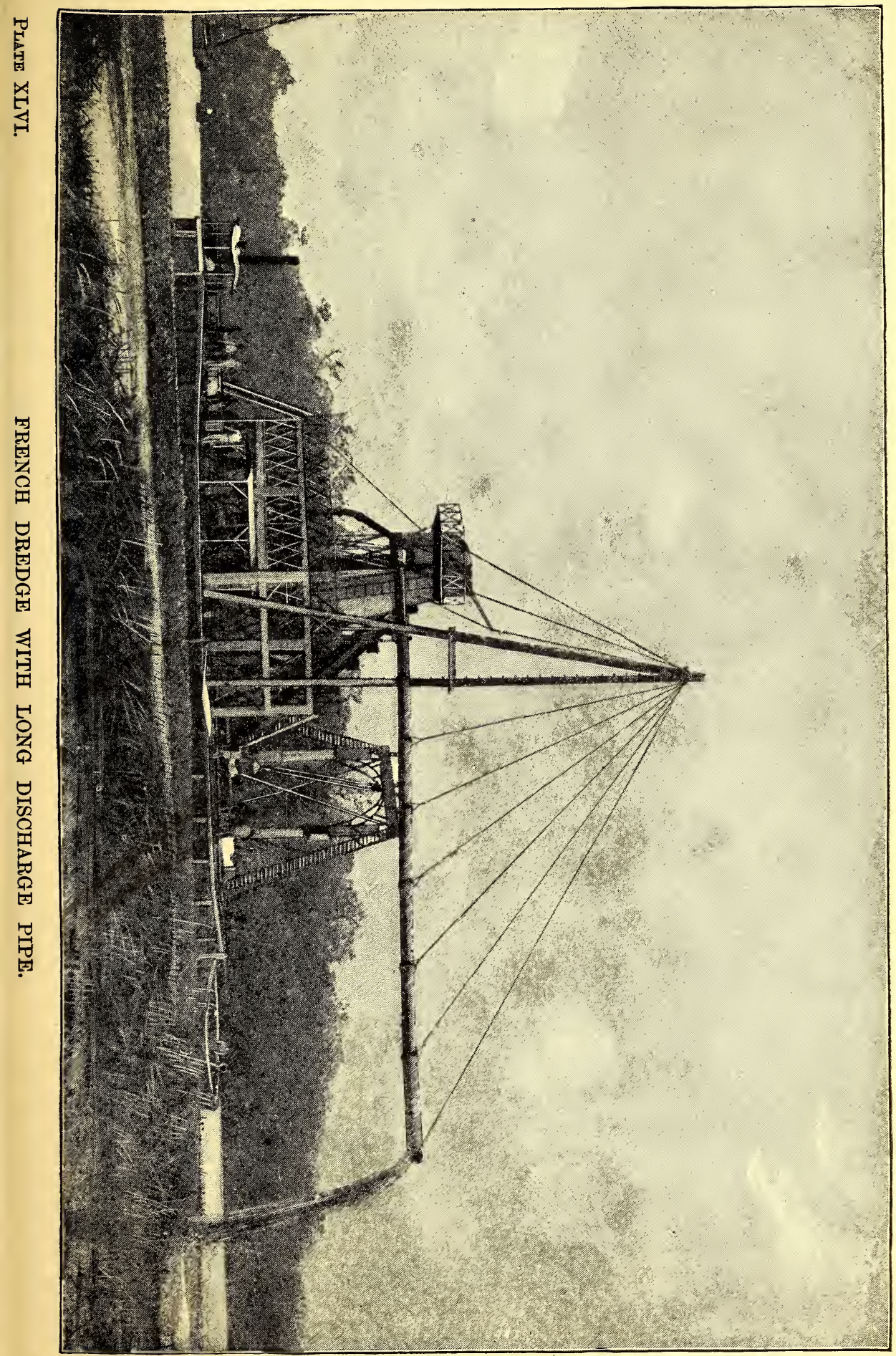



elongated and connected direct with cylinder of water pump. The three water pumps received their supply of water from the side of hull, and under high pressure from the cylinder it was forced forward to the hoppers. Amidships in the barge were built two hoppers with large cylinders and a small bottle-necked opening, receiving the discharge of material from the hopper of dredge, the material being well lubricated by water thrown into hopper of dredge through two 9-inch pipes. At the neck of hopper are two iron gratings, placed at right angles over each other, disintegrating the material which falls into the hopper. The outlet is at the bottom of hopper of 20 inches diameter and the entrance pipes for water force are three in number, entering the hopper two at the bottom, and on the quarter opposite the outlet pipe extending the stream to strike the material and drive it toward the outlet; also one pipe entering from above opposite the outlet and inclined in a downward direction; these three streams produced would meet at a radial point, the objective place of outlet of material. This gives the material a great force, depending upon the amount of pressure of the engine, and as the "chute" from the hopper of tower to hopper of barge is a closed pipe and filled with a continually falling mass of earth and water, it practically fills the full diameter of the pipe, making it air tight, so that with any induced pressure at the hopper of the barge, the only outlet of material would be through the bottom of the hopper, then out on shore through pipes located on pontoons. The advantages of this system are as follows : material does not come into contact with parts of pump, and in extreme cases when gravel work is to be excavated, the grate bars are removed, thus allowing all material to pass through the hopper when the size of obstruction is not larger than the cross diameter of discharge pipe. In dredging high banks, where the discharge must be made at some distance vertically and horizontally from the dredge, this is the best method in use. Also for harbor work when not affected by swells of ocean or surf, the endless-chain-ofbucket type attacking the material and discharging into hopper and from there floated to the shore by hydraulic discharge may be most expeditiously used. I would recommend that as this plant is quite expensive, the auxiliary barge, costing $\$ 20000$, should be coustructed separately from the hull of dredge, and may be used with hydraulic or Hercules dredges by proper connections.

In sand dredging the buckets revolved at a speed to fill 15 per 
cent. of diameter of pipe, the remaining 85 per cent. being filled with water, which must be at higher pressure than for clay work, as each particle of sand sets up for itself, and unless kept moving at a uniform rate will form sand bars in the pipe.

Clay should be disintegrated before going through the discharge pipe, as it forms balls uniting with sand, gravel or obstacles, and by rolling through pipe, hardens, and I have seen lumps issuing from the pipe of nearly three-quarters the diameter, thus blocking up the steady flow of water and material.

Belgian Dredge. (See Plate XLVII.)-This type of dredge used on the Panama Canal is quite similar to the French dredge, deriving its power in the same manner by sprocket and chain connection. The horse-power is two hundred, fitted with three horizontal fire-return tubular boilers, and two horizontal engines, whose pistons connect with crank shaft, on which is a wheel. I find in this system of deriving power that the teeth are constantly breaking. The revolution of the upper tumbler is not with constant velocity, as there are four distinct. movements or pulls each time the square upper tumbler goes through the arc of a circle. When the movement is constant then a toothed wheel and chain connection might be satisfactory, but I do not regard it as such in dredging tenacious material when a positive force more directly applied is necessary. The Belgian dredge discharges on either side into clapets, and the velocity of buckets was from fifteen to twenty per minute, each holding one-third of a cubic meter. I did not see any improvements on the machine other than were embraced on the French dredge. The cost was less than the French dredge on account of less tonnage, and I was informed they could be landed on the Isthmus at $\$ 90000 \mathrm{each}$; the percentage of construction varying largely, whether they were "set up" at Colon or some miles distant on the line, requiring shops and quarters for men to be erected at an additional expense. The complement of men ran from thirty to forty, and in French, Belgian and Scotch machines were arranged in only one watch, and these dredges only worked during the day, on account of liability of clapets running aground in steaming to and fro from the dumping ground at night from unsafe pilotage.

Rock DriLls.-A large consignment of the Ingersoll type of rock drills was sent down to the "Société de Travaux Publiques" for use at Bas Obispo and at Emperador. These drills were in use only a few 

days, on account of insufficient number of skilled foremen to instruct the native labor in using them. Consequently the whole plant was abandoned. I did not see any machine drills in operation in crossing over the whole line, and the most modern plant which has accomplished such a wonderful work upon our New York Aqueduct has been sidetracked at Panama for reasons dependent upon labor.

The French Machine Driuls have proved a cumbersome appliance for all styles of work and uneven ground. A platform car, mounted on four wheels, supports a horizontal boiler of 15 horse-power. An upright frame supports four drills 3 feet apart, and these drills are raised and lowered by a ratchet and pinion attachment in the frame. A circular motion is communicated to each drill by a shaft from the main engine fitted with a beveled wheel. The drill is operated by a circular movement, being a borer rather than an up-and-down stroke. The contact of drill, holding it to its work, is regulated by hand of foreman of the machine. In order to work, a track of 5 feet gauge must be constructed upon the area subject to drilling and excavation, and the machine run on this railway at different points, set to work, and holes drilled to required depth. When a sufficient number of charges have been put in, the machine is run off the rock and the track removed and the number of holes fired by electricity. This cumbersome process is expensive on its face, as tracks must be constructed and removed, which can only be accomplished on level ground expeditiously, limiting the machine to level work, while an Ingersoll drill can be stationed on hilly and uneven ground, drill vertically, downward, or upward, or obliquely; no tracks are needed, and only men to transport the weight of the machine from place to place.

A Submarine Rock Dritu has been successfully used on both ends of the line, and one at Fox River, at Colon, was built as follows: The hull of boat is 50 feet long by 20 feet broad, supplied with boilers for self-propulsion by screws and for communicating power for drills. Forward in the boat is an open square, 15 feet wide by 20 feet long, over which is a traveling frame supporting the drills. This frame has a fore-and-aft motion, running on tracks at each side of the boat. An extension shaft from the crank-shaft by beveled gear wheels, transferring the power to top of frame, communicates the motion to drills, which are four in number, and are supplied with a screw end acting as a borer. A telescopic pipe, water tight, is lowered from the 
frame of the drill and is driven down into the bottom of channel, and the drills are then lowered and commence work inside of this watertight sleeve. The four drills make their holes, when the drill is withdrawn, and the charge put in and wired, the wires brought up out of the water and made fast to the deck. Then the frame is moved forward on its tracks a few feet and four more holes are drilled and loaded. The hull is controlled by fore-and-aft guys and side guys, thus limiting its work over a certain territory. When the area over which the open slot floats is charged, the hull is moved, and successive holes are drilled, when the boat withdraws a safe distance and the blast is made. The coral rock at Panama and Colon has been disintegrated in this manner and when broken in small pieces has been attacked by the dredges. I regard this means as quite successful in deep submarine work, and economical. The cost of an iron hull would be three to five thousand dollars with boiler and fittings of drills, and entire plant would not be over $\$ 2000$ more.

Buasting.-Besides the holes of small diameter used in excavation of rock, larger shafts are resorted to, in cases where the material is of volcanic formation and porous, causing a charge to blow out in the cracks of the different strata. A hole 1 meter square is excavated some 10 meters in depth; at the bottom of this shaft two chambers are extended in either direction, 1 meter square and 2 meters each, long. These chambers and the shaft are filled with barrels of powder and dynamite. At a distance of 5 meters below the surface of the ground cement is used as a filling, and after setting forms a solid mass of artificial stone to the surface of the ground. A number of these shafts are made and all fired at once. This immense explosive force shatters the surrounding mass, which may be easily attacked by the workmen with picks, loaded into buckets, and swung around and dumped into cars by cranes. In soft rock this has been the only successful means of working, but is costly on account of the large quantity of powder used in filling and loading the shafts.

The large works in hand are all accomplished at the present time by the use of churn drills, the ignorant workmen using drills from 6 to 15 feet long, of different diameters. They receive twenty-five to thirty cents per linear meter for holes of 6 to 8 feet in depth or under, and where the holes are over 8 feet in depth they receive from thirty to forty-five cents per linear meter, the quality of rock regulating the 
schedule of prices largely. These prices include the labor of loading and firing the holes, the cost of material to be furnished by the contractor. The cost of transportation in using rock drills, on account of weight of boilers and drills and frame, becomes an objectionable feature, and the general policy has been, in the absence of intelligent men, to pursue such simple means and appliances that when the ignorant force is left alone and, without oversight they can accomplish satisfactory work, hence the substitution of the churn drill for our effective mechanical system.

Steed RaILS. (See Rail Section, Plate XLVIII). - For construction purposes a rail weighing from 40 to 55 pounds per yard, and with base equal in width to the height, would be 'of' sufficient strength, where the maximum weight at any one time is a French excavator of 36 tons, whose base is 30 feet; ties 2 feet from center to center. I find that one most costly mistake has been made on the Panama Canal by ordering for construction purposes over 120000 tons of 70-pound steel rails, of suck dimeusions that the height largely exceeds the base. The Belgian locomotive weighs 30 tons, having three drivers and a rigid base of 13 feet, so that in curves of small radius or over 8 degrees the overturning movement is so great as to cause rails to spread, drawing the spikes. This has caused many derailments, and especially on construction tracks which are improperly ballasted the rail and tie must stand the whole strain. Then again on dumps or terraces where tracks must be frequently moved from side to side, it requires a larger force of men to do this work than if handling a 50-pound rail.

Steam Engines. - The following firms are largely represented by their engines upon the Isthmus: Société Cockerill; Société Belgique; Société Anonyme de Couillet Belgique; Rogers Locomotive Works; Baldwin Type of Burnham, Parry \& Williams. The Belgian locomotives are quite similar in construction, weighing 30 to 40 tons, supported by three drivers on each side, connected rigidly, the middle driver having no flange. Their capacity is hauling twenty-four loaded dump cars, weighing 10 tons each, up a three per cent. grade. They consume about three tons per day, and require a crew of three men and engineer. Wages of engineer, $\$ 4$ to $\$ 5$ per day; wages of men, $\$ 1.50$ to $\$ 2$ per day.

The foreign machinery is much heavier than the American, burns more coal, and gets much more easily out of order. The foremen and 
engineers on the line of canal prefer the Baldwin locomotive, manufactured by Burnham, Parry \& Williams, for rapid work and easy control of parts. The Rogers engine is also in good form, and both American engines consume less coal than those of foreign manufacture. The cost has varied from $\$ 12000$ to $\$ 15000$, delivered at Colon.

De Cauviule Cars (See Plate XLIX). - The De Cauville system of pan cars includes two styles, namely, the De Cauville and Baillard plant. The Baillard cars are of box shape, holding $\frac{1}{2}$ cubic meter. The iron frame of truck is solid and holds the boxes of the wheels. The box is of iron, baving a semi-circular arc at each end, resting upon a grooved track, and in dumping the body of the car travels on "the arc, throwing the box through an angle of 45 degrees. Their weight is 500 pounds, and cost $\$ 50$ to $\$ 60$ apiece. The gauge is 20 inches.

The De Cauville car is quite similar in the construction of truck, but the body of the car is shaped like a triangle, base uppermost, and supported by two lugs at each end, fitting into an upright frame made fast to truck. The center of gravity is in equilibrium when the car is full and it may be easily dumped by throwing the body through an angle of 45 degrees.

This size runs two and a half to three per cubic meter. The skeleton track is of 20-inch gauge and constructed in sections of 15 feet, the iron ties being made fast to the rails and easily transported in small space in large quantities. This plant is not in use with mules or horses on the Panama line, and I have seen numerous instances where they were used by the natives in executing task work, when they would receive thirty cents per cubic meter for filling and pushing cart to dump, several hundred feet, when by mule or horse labor and train of six or eight cars to each animal they could be hauled to place more economically. This plant is far superior to any invention in the States as a light and economical means of attacking preliminary work. In preparing cuts for excavators and in surface work where irregular territory is to be smoothed down for location of heavy construction tracks for steam excavators this plant is expeditious.

Broken Stone. - I found a French stone-breaker at work at Pedro Miguel and at Buhio of larger and more massive construction than a similar American machine. The broken stone for the locks at Buhio, San Pablo, Bas Obispo, Emperador and Paraiso is all task work and executed by hand, the men receiving $\$ 2$ per cubic meter, and in many in- 


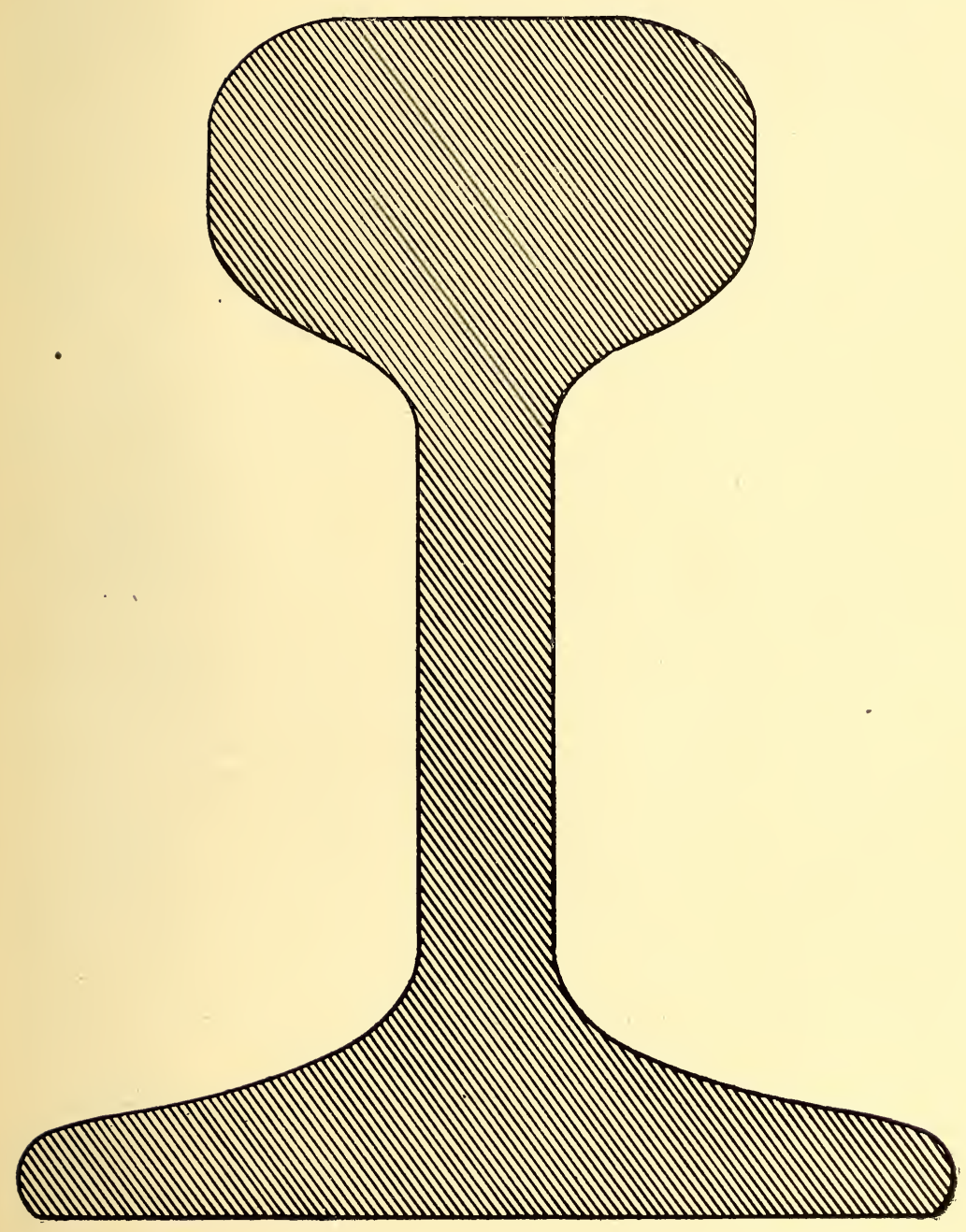

\section{SECTION OF. RALL USED FOR CONSTRUCTION ON THE PANAMA CANAL. \\ PLATE XLVIII.}


stances quantities of the stone broken during the last year has been of such quality that when exposed to the atmosphere it became disintegrated and crumbled. In nearly all cases of rock excavation for the locks at San Pablo, Buhio, Bas Obispo, Culebra and Paraiso solid stone is not met in the upper strata, and at the quarry of the Panama Railroad, at Buhio, is the only large quantity of stone suitable for masonry and concrete.

At several points along the line I noticed the broken stone had been whitewashed, and inquiring the reason, was told that the Jamaican laborers, during the night, would steal broken stone from one another's piles, which has been paid for at $\$ 2$ per cubic meter by the contractor, the laborer turning in the stone to be paid for over again, and the contractor was obliged to adopt_a whitewashing system to distinguish work paid for from that not accepted.

Submarine Rock Work.-In connection with the submarine rock drills may be mentioned the grapplers in use on the Panama line. They are constructed very much on the same principle as cranes, and the hull is large enough to support a 10 horse-power boiler, horizontal engines and crane swinging through an arc of 270 degrees. Attached to the crane are the grappling irons, operating like a clam-shell dredge, and these teeth are lowe :ed to the required deptb, grappling the broken rock, which is hoisted to the surface, the crane swinging the load and dumping into a barge alongside. The hulls of these machines are constructed of iron, in sections, the hull being $40 \times 18 \times 6$ feet deep, and have been largely usel in removing coral rock on the Colon side, which has been first broken up by drilling. These machines, on account of size of hull and easy means of handling, are able to move in shallow water and work in closer quarters than if cranes and grapplers were applied to each dredge, as in the Hercules work, and in using them separately from the dredge much time is gained, as the dredge can keep on with her work, and independently of rock which may be afterwards excavated.

Cranes. (See Plates L, LI, LII.)-Rock work in nearly all cases was executed by the use of steam hoisting cranes, which were used in large variety and of the following manufacture :

1st. J. Voreez Ainé, Nantes, 1887 ; 2d. Stothert \& Pitt, Bath, England ; 3d. Applegate Bros., London, England.

The first named was of the "goose-neck" style of crane, which was supported on four wheels, car of 5 -feet gauge, the whole crane weighing 


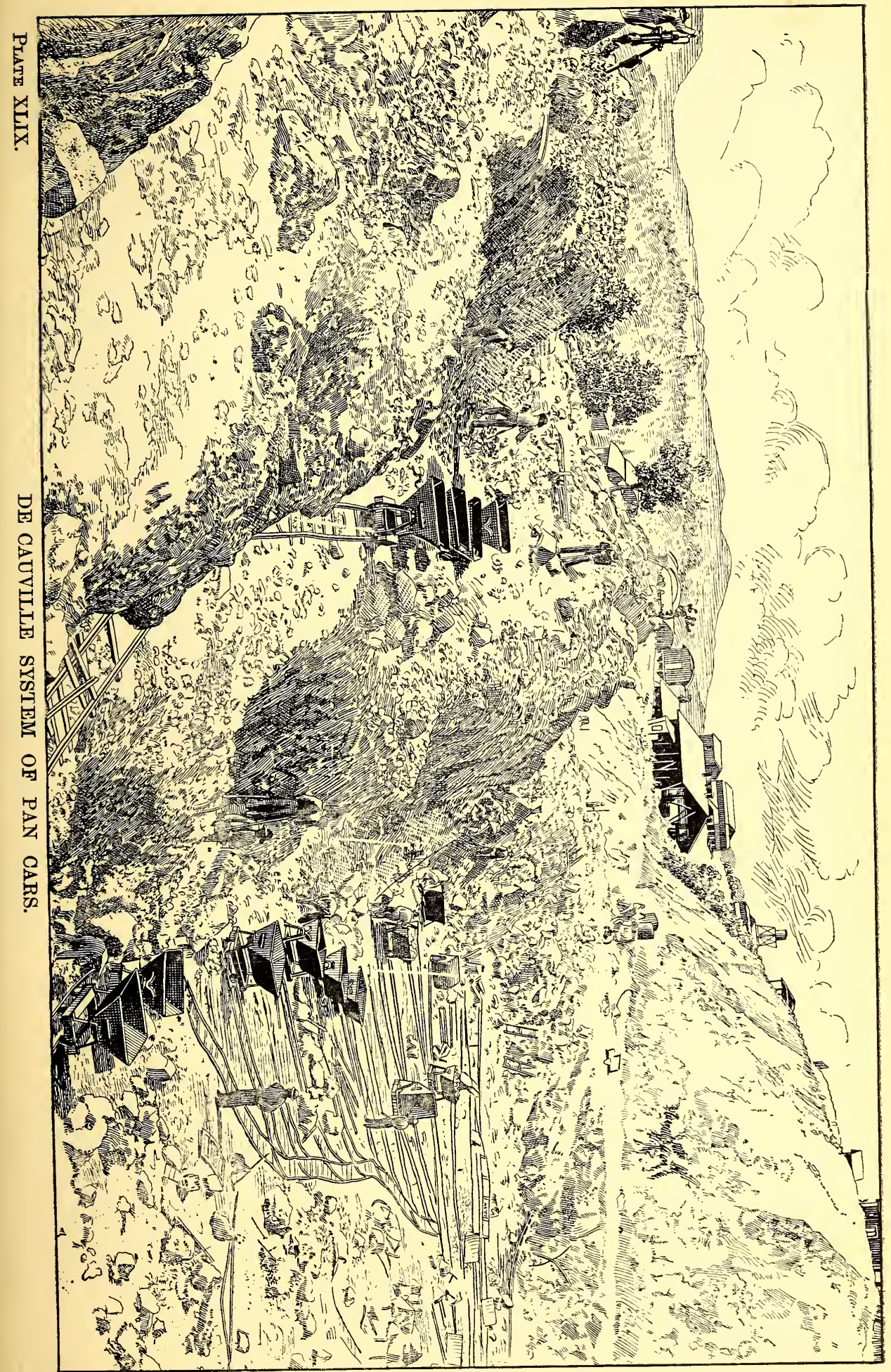



10 tons and having a lifting power of 4 tons. These several machines were of the same weight, and the efficiency of work was dependent upon the manner of deriving power from the engine in hoisting the weight. In the first machine a friction clutch was used, being easily thrown in and out of gear, the hoisting drum receiving the chain from the crane, and paid in and out at the control of the engineer. An endless-belt con. nection with the crank shaft, and running around the sprocket wheel on the car axle, furnished propulsion. The body of the crane rests on a central axis, allowing it to swing through a circle. The axis of the crane has a large gear wheel, into which fits a smaller gear wheel, receiving power from the crank-shaft. The mode of action is as follows: The rock, when broken up, is loaded by hand into wrought-iron cylindrical buckets, some holding $\frac{1}{2}$ cubic meter and large sizes holding 1 cubic meter, the task men receiving twenty to thirty-five cents per cubic meter for this work. The buckets are made fast to the end of the chain and the engineer of the crane hoists them up and swings them around onto cars, where they are dumped. The capacity of work has varied largely, but at San Pablo and Bas Obispo they average nine cars a day of 6 cubic meters each; but this is much too small, as when properly supplied with buckets they might accomplish at least 100 cubic meters work. A limited number of men working in a small area could fill only as many buckets as space would allow; and meanwhile the crane might travel up or down the track to different squads of men, hoisting and emptying the buckets as fast as filled, the dump-cars standing on the second track, behind the track of crane, and in this manner would accomplish a much greater amount of work. In the rainy season, when construction tracks are difficult to keep up, this crane is especially useful, as, on account of its light.weight and low center of gravity, it is not as easily upset as excavators, and it has been frequently used in earth work. The working force necessary is one engineer to each crane, paid $\$ 3$ to $\$ 5$ per day, and one fireman to three cranes, receiving $\$ 2$ per day; one carman and one bucketman to each crane, $\$ 1.50$ each per day. The coal used per day averages $\frac{1}{2}$ ton. In machines Nos. 2 and 3 the power is derived from a gear wheel on the crank-shaft connecting with the gear wheel of the hoisting drum. The boilers are horizontal and the center of gravity is thrown as far to rear of crane as possible by loading the platform on back with rails as heavy ballast. When ready for work the frames are in some cases "jacked up," giving a wider support for a working base, 
as the arms are 8 feet centers and jacks 7 feet apart. Of the five varieties in use, No. 1 has executed good work, and the less liability of parts to get out of order is an important element. These machines are built in sections and transported and put up on the scene of work. Cost, F. O. B., about $\$ 5000$.

Ponton Biques. - Large floating cranes are used at Colon and Panama in trans-shipping a heavy cargo from deeply laden vessels of large draught, on account of their inability to run alongside of the canal wharves. The largest size has a lifting capacity of 40000 pounds. The hull is $60 \times 30$ feet and of 10-feet draught, supporting a derrick on the forward end of 75 feet height and a reach over sides of hull of 30 feet. This crane has been used in lifting the heavy sections of dredges from the holds of ships, and swinging them around and loading them onto flat cars of the Panama Railroad for shipment upon the line. This crane has the power of a stationary crane, and may be moved from place to place when necessary, by a system of guys, which are reeled up on hoisting drums on board of the ponton. The crew necessary is, one engineer, one fireman, one man on the tower, two men in charge of guys, engineer in charge of hoisting engine, and engineer in charge of "swinging derrick." The use is limited at Colon to unloading vessels and it is seldom at work more than half of the time. On account of gaining the proper stability it must have an immense hull to support the weight. The entire plant is expensive in the extreme, and if a proper wharf had been first constructed, dredged out its entire length, and a track laid to allow the passage of freight cars, a permanent crane might have been erected at half the cost and less expense of operating.

Marine Cranes. - I noticed a number of self-propelling steam cranes at Colon, having a capacity of hull to hold 500 tons of freight. These cranes went alongside the steamers, made fast and discharged the cargo of the steamers, receiving it with the chain and crane, and swinging it around to the hull of crane until filled, when another crane would come alongside and repeat the operation. These cranes would then steam up the line and unload at the different shops or storehouses. In all cases they were used in unloading the heavy parts of machinery, such as boilers of dredges, excavators, cranes, locomotives and dump cars. Their capacity was 10 tons and usually two cranes were mounted on each hull. These floating cranes of this size I regard as indispensable, as at some time all available wharf room might 



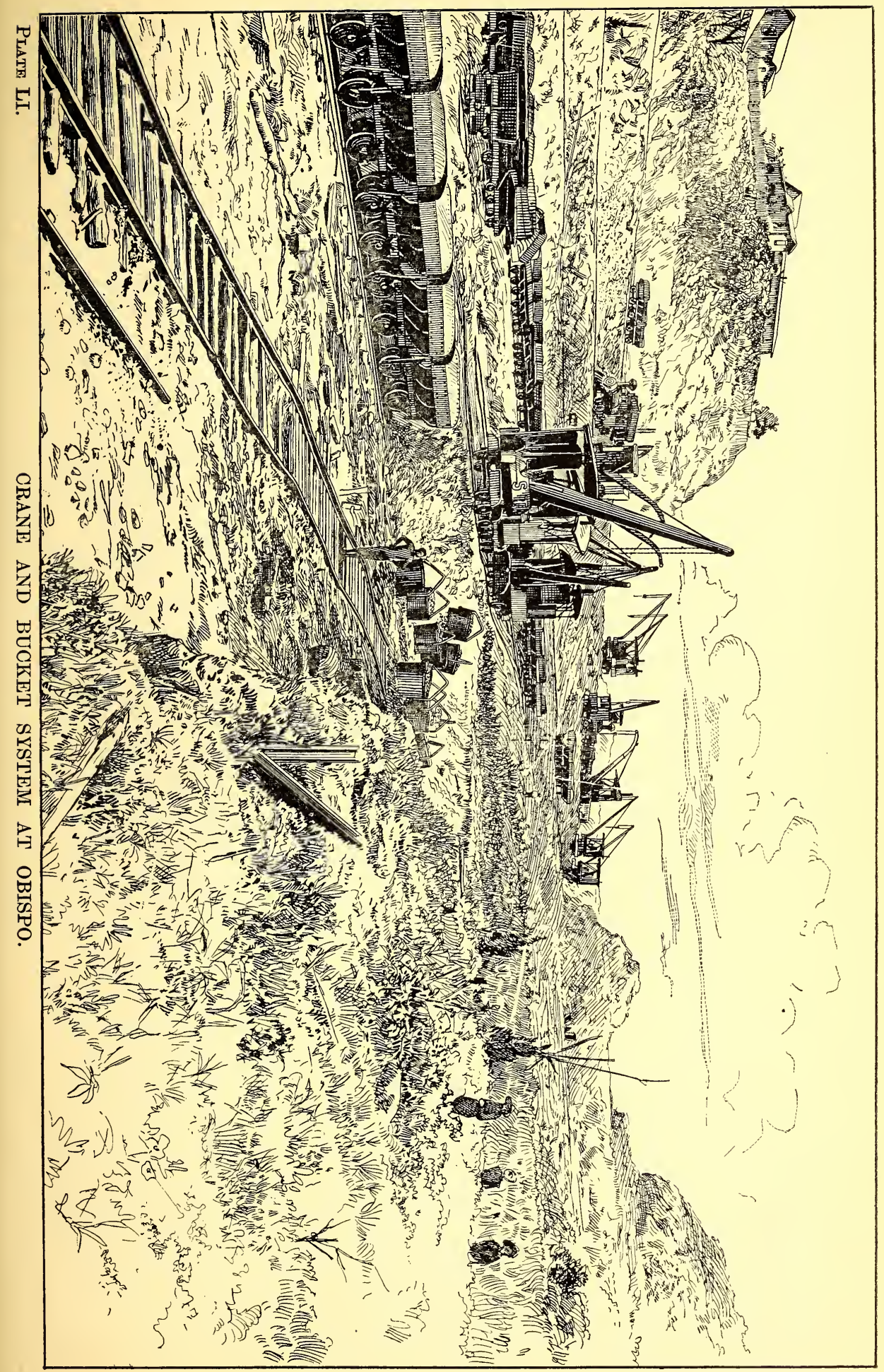




be in use and a steamer arriving at this time would suffer demurrage in not bəing able to discharge her cargo, while a floating crane might make fast alongside when the steamer was anchored in the harbor, and discharge into the hull of crane, or upon scows alongside. Many steamers are provided with cranes or use tackles and yard arms, but it would be slow work as compared to a distinct plant for the purpose.

Excavatons (See Plates LIII, LIV, LV, LVI, LVII).-Many styles of the endless-chain-of-bucket excavators are in use, but after a thorough examination as to machinery and work accomplished, I consider the machines constructed by P. DeMange and Messrs. Satre \& Lyons superior to any others. This machine is constructed on two trucks of four wheels each and of a 5-foot gauge, while when in working condition the working base is broadened by jacking up and throwing the weight on the working side out to a third rail 7 feet distant from the line rail. In transporting the machine from place to place the construction track of 5 feet gauge is adequate, and in working a third rail is laid up and down the line over which the machine is to travel. The ladder over which the buckets travel is hung on an axis on the back of the machine, but throws the center of gravity towards the working side, and to offset this, ballast of railroad iron is loaded on the extension on the back of the machine. The boilers are usually horizontal, giving low center of gravity, and the water tank of iron and a coal bunker of iron are placed on the boiler end of the platform. There are two styles of attacking a bank, called " down diggers" and " up diggers," whether attacking material above or below level of track. A "down digger" of the above manufacture at work at Tavernilla may be described as follows (Plate LIII): The endless chain of buckets operated on "over and under" system received their motion from the square upper tumbler of the shaft, which was geared from its wheel of large circumference, connecting with a smaller gear wheel on the crank-shaft. The vertical engine supplied this shaft with 3 pistons, giving a positive motion. The buckets were constructed with a quadrangular hemispherical face and no back, the links being hung at the back of the bucket, and the ladder being suspended down the bank, was raised or lowered to give a slight contact to the cutting nose of the bucket, which became filled by gradually cutting a slice all of the way up the bank, carrying the material up and onto the upper tumbler shaft, and as the bucket at a slope of 45 degrees to the horizontal changed its angle by going over the upper tumbler, no sup- 
port was given to the contents, which fell out and down into the hopper, and through a "chute" suspended over a train of dump cars on the second track and back of the machine.

The engineer of the excavator controls its movements entirely, raising and lowering the ladder, also moving the excavator up and down the track by an endless belt running from a sprocket wheel on the crankshaft of the engine to a sprocket wheel on car axle. With good executive management and a constant supply of cars under the chute this machine could excavate 200 to 300 cars per day of 6 cubic yards each.

The force necessary to work is as follows:

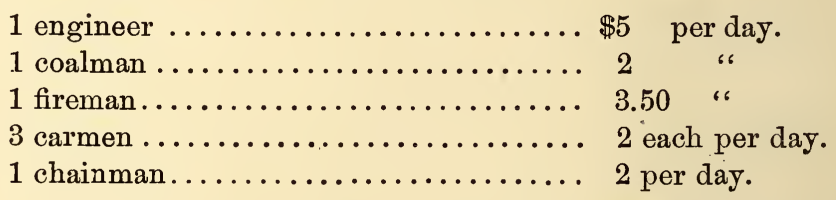

In connection with the excavator would be needed two locomotives, with fifteen to twenty cars each, depending upon the distance of the dump from the centre of excavation and the grades to be overcome in traversing the distance. The consumption of coal is 3 tons per day. In sand and soft clay and dirt the machine will do efficient work, and in the Culebra Cut I noticed one of the machines doing slow work in broken rock. The stability of the machine is also controlled by clamping the frame of the machine on the rear to the track.

The Osgood Excavator. (See Plate LIV.)-I saw three of these machines at work at Culebra and Paraiso, which were amongst the original shipment of seven sent from America. The boilers were vertical, of 50 horse-power, cylinders 10 by 12 inches. Buckets holding 2 cubic yards, struck measurement. Cost was $\$ 8000$, F. O. B. at Albany, N. Y. The working force was as follows:

1 engineer................... $\$ 4$ to $\$ 5$ per day.

1 dipper tender............... 2.50 to $\$ 3.50$ per day.

1 fireman.................. 1.75 per day.

6 men shifting truck, carrying water, etc............... 1.50 per day.

Consumption of coal............ $1 \frac{1}{2}$ to 2 tons.

This type of machine is supported on two trucks of 5-feet gauge, and when in position for working the forward truck of the machine is 


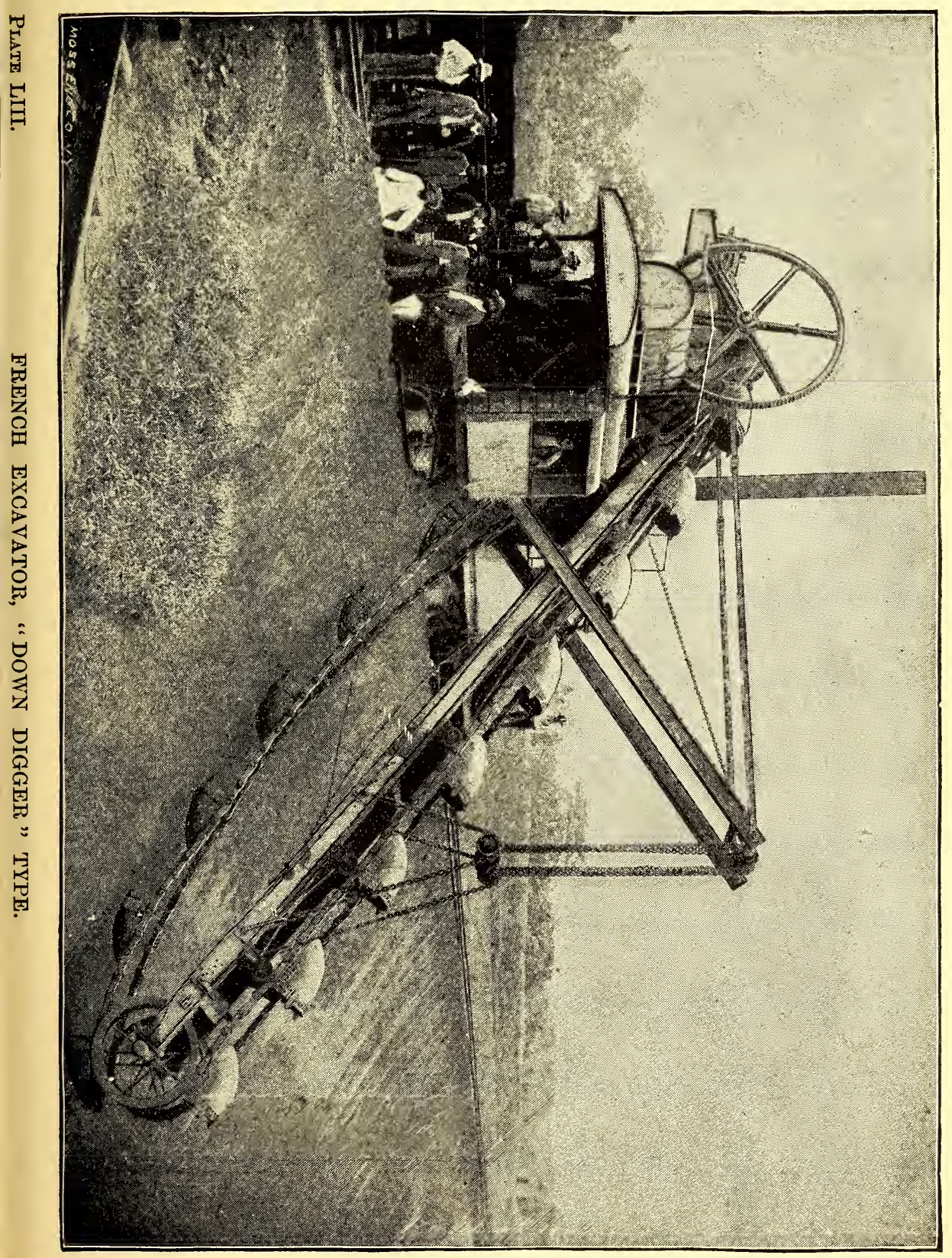




jacked up, throwing the weight off the rails, and the outriggers of 8 -feet centers are used instead, giving a wider working base. The weight of these large type of machines is about 30 tons. Self-propulsion is gained by an endless belt connection with the main engine shaft to the rear axles. Water tank and coal tank are placed on the rear car near the boiler. These machines will excavate a cut up to 70 feet in width, and dump contents of dipper' 29 feet above track. The mode of action is for the excavator to start at face of cut and gradually excavate forward and on each side, of sufficient width for the placing of two tracks, one on each side of the excavator, which may move forward in reaches of 8 feet, each digging her own track. Dump cars are brought in alongside on either track from the rear switches by cable connection winding around a drum on the exterior of the body of the excavator; these cars when filled are hauled out onto main line, and empty cars are in readiness to supply their places. The dipper delivers first on one side, then on the other, the cars being constantly supplied. Under favorable conditions and management, in sand and loose gravel, as high as 2000 yards per day of ten hours have been accomplished. In hard-pan and obdurate clay satisfactory work has been done. The engineer on the platform of the car operates the engine, lowering or raising the dipper, swinging it around onto the cars, while the dipper tender standing on the turntable crowds the dipper to its work and empties it. I found in all cases the "Osgood" machine spoken of in the highest terms, as doing a larger amount of work with less force of men and less liability to get out of order than those of foreign manufacture, and the fact that it was able to help itself, preparing its own track, enables it to work in all places where the endless-chain-of-bucket type would be useless.

Excavator "UP-Digger." (See Plate LV.)-These machines are constructed receiving their power in two ways from the main engine, by direct connection of piston to crank-shaft, on which are balance wheels, and two small gear wheels gearing into wheels of large diameter on upper tumbler shaft. This supplies a positive power, so important for a machine at work in stiff clay and hard-pan. The other means of doing this is applied in the Suez Canal type of excavator, which receives power by the sprocket-and-chain connection already described as used on the French dredges.

In the "up-diggers" the buckets are constructed similar to buckets of the dredges, and have the under-and-over movement. 
The weight of these machines runs as high as 36 tons ready for work, and to this must be added the weight of the dirt of one-half the number of buckets filled, so in many cases the weight will reach 50 tons. In the larger type a third rail is placed 7 feet from the rail on the "line side," thus throwing the weight of ladder and derrick on the outer rail, while clamps on the line side are easily adjusted on the track and body of the excavator, preventing any overturning. The "up-diggers" are limited as to the amount of work they are to execute, on account of the short length of ladder in use, and the track must be constantly "thrown," in order to give a steady working contact with the bank. In working "down-diggers" and "up-diggers," a supply of cars should always be on hand, so that when one train is loaded and starts off for the dump, its place may be taken immediately by a second train. This item is alone important in the capacity of work of a machine, and a foreman of intelligence should always be placed in charge, so to regulate switches and side tracks as to cause no demurrage. In the rainy season it has been found impossible to keep up the tracks at Culebra and Tavernilla, and the excavators have all been abandoned and cranes substituted. The "down-digger" machines rest on the edge of the terrace, and the slope, inclined at an angle of two to one, is not flat enough to prevent a sliding tendency of the bank caused by a 50-ton weight, and a vibratory movement arising from the contact of the bucket with the bank. With the "up-digger" at work in the rainy season the same sliding occurs, the limited swing of ladder (in many cases the working side of machine being only 10 feet from the perpendicular bank, which caves and slides) causes the tracks to be covered up.

Excafators and Transporters. - At Tavernilla, in connection with the endless-chain-of-bucket excavator, was employed a transporter (Plate LVI). A truss of 500 feet in length was supported at one end on the deck of the excavator, and extended at right angles to the fore and aft line of work, the other end being supported upon a traveling derrick and car. This truss was 6 feet in width and 10 feet in height, and an endless belt $4 \frac{1}{2}$ feet wide received motion from an independent engine of the excavator. The contents of the buckets of the excavator were discharged into the hopper and out onto this traveling belt, thence along over top of truss until the end was reached, when, the belt going over the outer tumbler, its contents fell to the ground. The outer end of the truss may be raised as high as 30 feet from the 


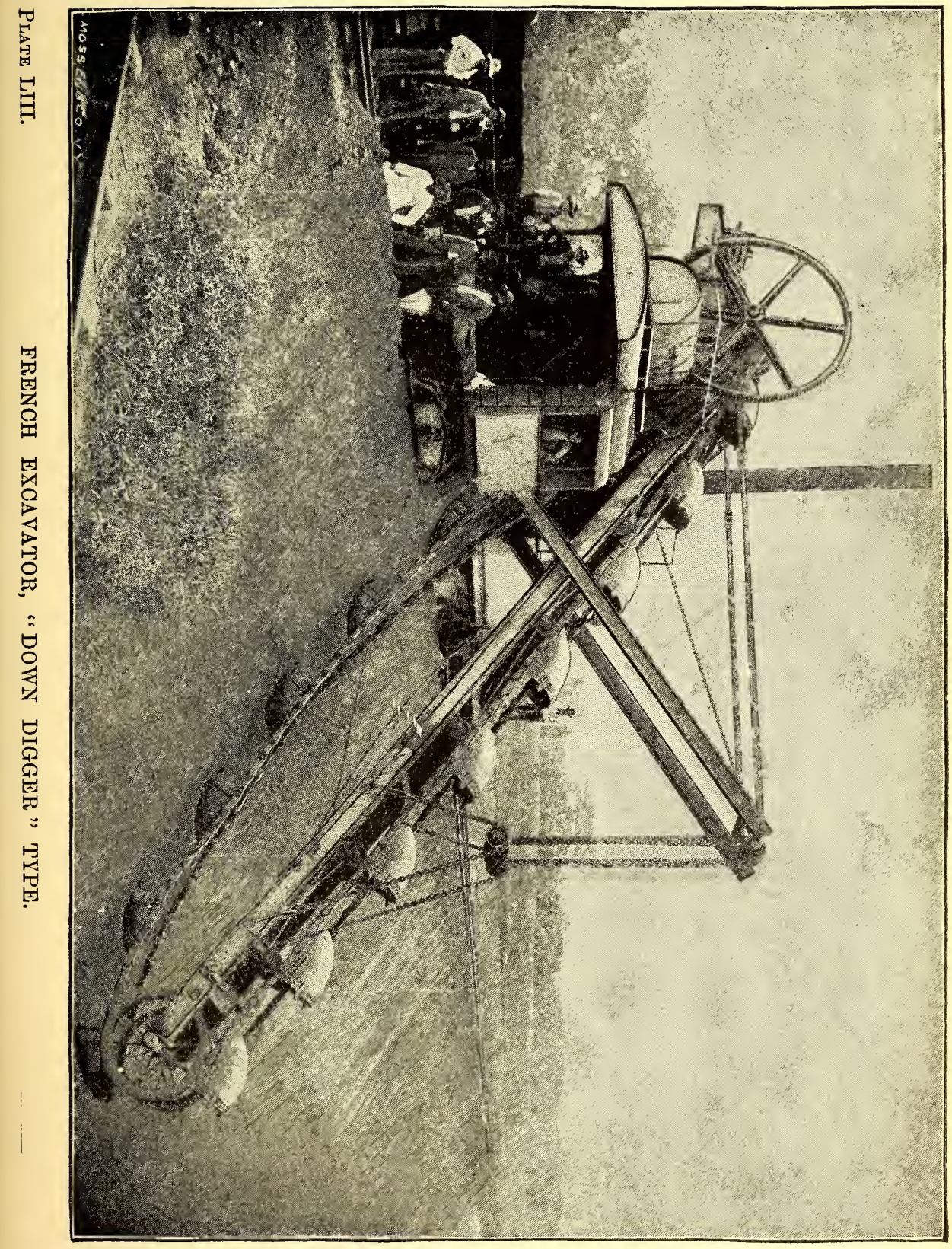





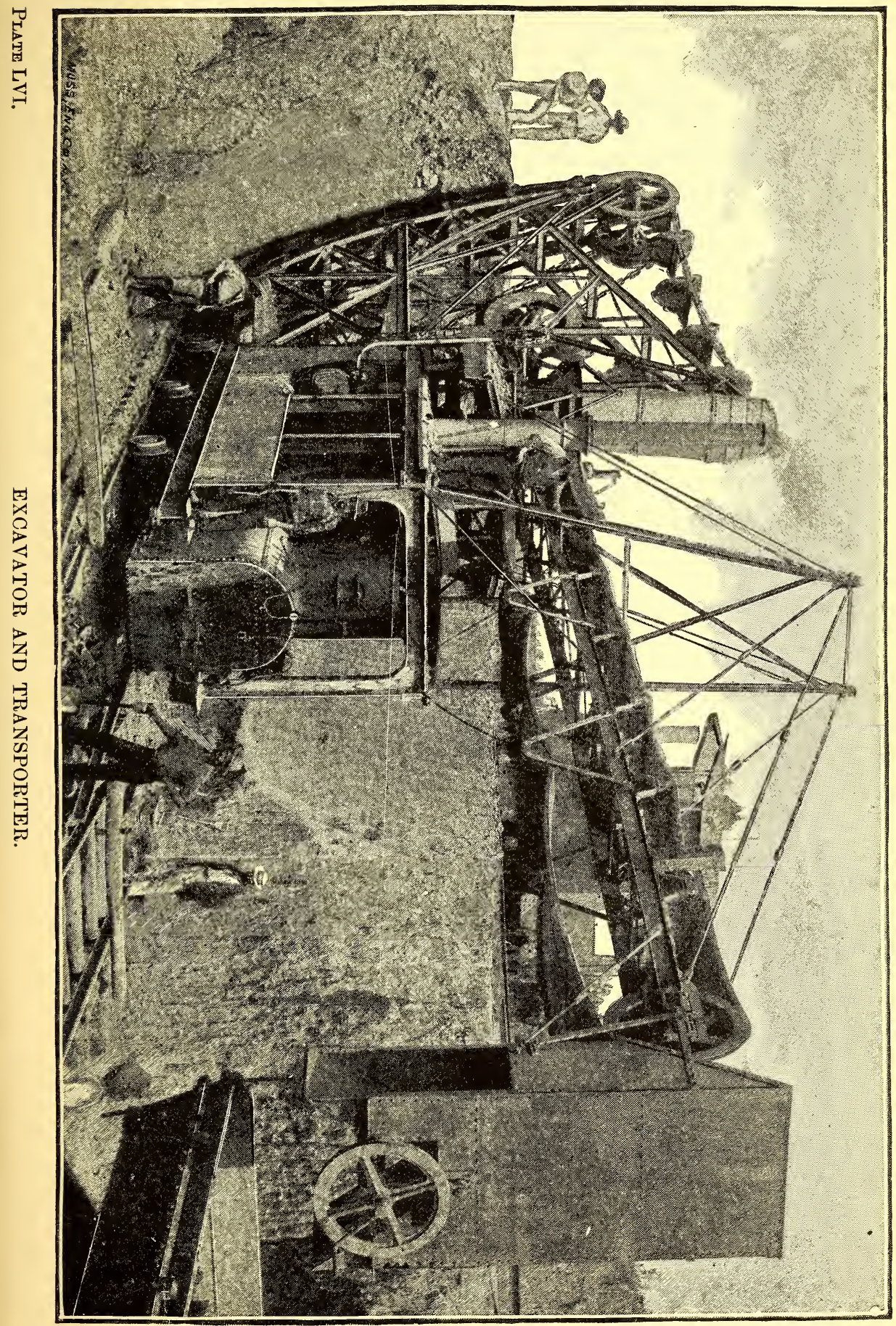





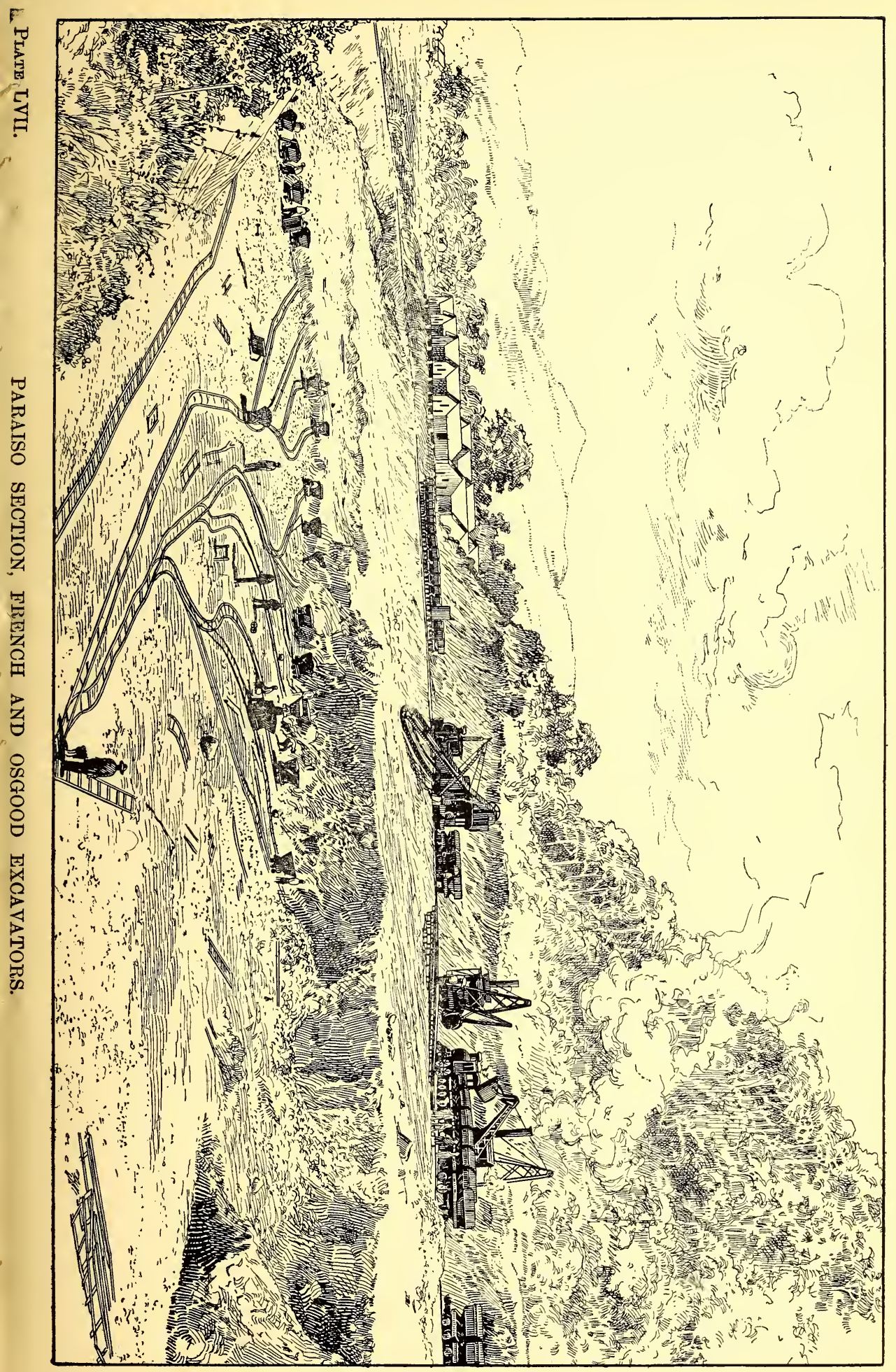



ground, giving room for a large bank to fall without obstructing the passage of derrick car from the débris sliding toward the machine. In this work the excavator was digging 30 feet below the rail of the car, material was carried 500 feet distant and elevated a total of 50 feet. This necessitated the keeping up of three tracks, the two tracks of excavator, and a track of platform car, supporting belt, engine and boiler, and track of derrick car. In addition to the regular crew of the excavator there were used one man on the derrick car to preserve a constant forward motion up the track with the excavator, one engineer on the platform car to regulate belt engine, and one fireman each for derrick car and platform car. The use of this extensive plant is limited to the following case: In deep cuttings, where a depth of over 50 feet is to be made and over a length of several hundred feet, it is necessary to throw the material so far back from the center as to be outside of the slopes when the requisite depth is obtained. In this first cutting of 30 feet, throughout width and length, the material may be handled automatically and deposited by the transporter, but here its usefulness ends. In the second cutting of 30 feet the material must be hauled away by cars, and tracks constructed up and out of the cut, and to some dumping ground, as in going down deeper with the excavation the dump rises vertically, and the transporter would be at too great an incline to work economically.

CuAPETS. - The self-dumping steam clapets were all of French construction, the hulls in many cases being constructed.in sections in France and sent over to the Isthmus and set up at the foundries and shops at La Boca and Colon. The capacity varied in instances from 150 to 300 cubic meters, the length of hull being from 75 to 120 feet. Propulsion was from the aid of twin screws, and the draft of water when loaded 10 feet and under. These machines were supplie 1 with hinged doors on the bottom of the scow, opening outward, and were opened and closed by chains on the hoisting engines. They are much easier handled than self-dumping scows operated with tow-boats, and the time occupied in running up to the dredge and making fast is reduced to a minimum, usually attaching and detaching in ten minutes. The cost of these clapets was as high as $\$ 20000$ constructed on the Isthmus. The complement of men was as follows: 
1 Captain......................\$200 per month.

1 Mate.......................... 120 " "

1 Engineer ...................... 120

1 Cook........................ 60 "

2 Firemen....................... 50 "

10 Deck-hands..................... 45

1 Donkey engineer ................ 45 "

The contractor supplying board.

Houses for Men.-The common type of quarters for men along the line of the Panama Canal was to erect a light frame-work of wood, the sheathing being horizontal and of spruce, the roof of corrugated iron, and either round or peaked. Stationary beds were erected for the men through the center of the house in rows of two deep, and houses of 50 by 30 feet will accommodate 40 men. The foundation was constructed of rough ashlar masonry or concrete in piers located under the corners, quarters and centers of the floor, in most cases the house being raised bigh enough to allow free circulation of the air underneath. "Flying Houses" are frames built of light angle iron with corrugated iron roof and sidings, and are largely used for machine shops, when the use will be temporary. They can be easily taken apart and transported from place to place by removing the bolts holding the sections, while with wooden structures, nails and bolts 'being used, the timbers would become broken, split and decay in a short time. Tile roofs are much cooler than corrugated iron, but more expensive, while shingles decay in a year's usage. Asbestos and gravel roofing have not stood repeated tests, corrugated iron having given the best satisfaction.

Dump Cars-Everard System. (See Plate LVIII.)-I saw many wooden systems of dump cars, built in some cases of creosoted wood in order to resist the action of the climate, but I found upon examination that all cars so constructed did not last as long as those built of wrought-iron. The body of the car being subjected to the concussions of heavy weights falling from the hopper of excavators soon became fractured. These cars were constructed of 5 -feet gauge and four wheeled, the axle and frame-work and body of cars being easily taken apart and occupying small space. There were two sizes of bodies, one holding 4 cubic meters and one holding 6 cubic meters. The weight of the larger car was 5 tons unloaded, and when loaded with 6 cubic meters 


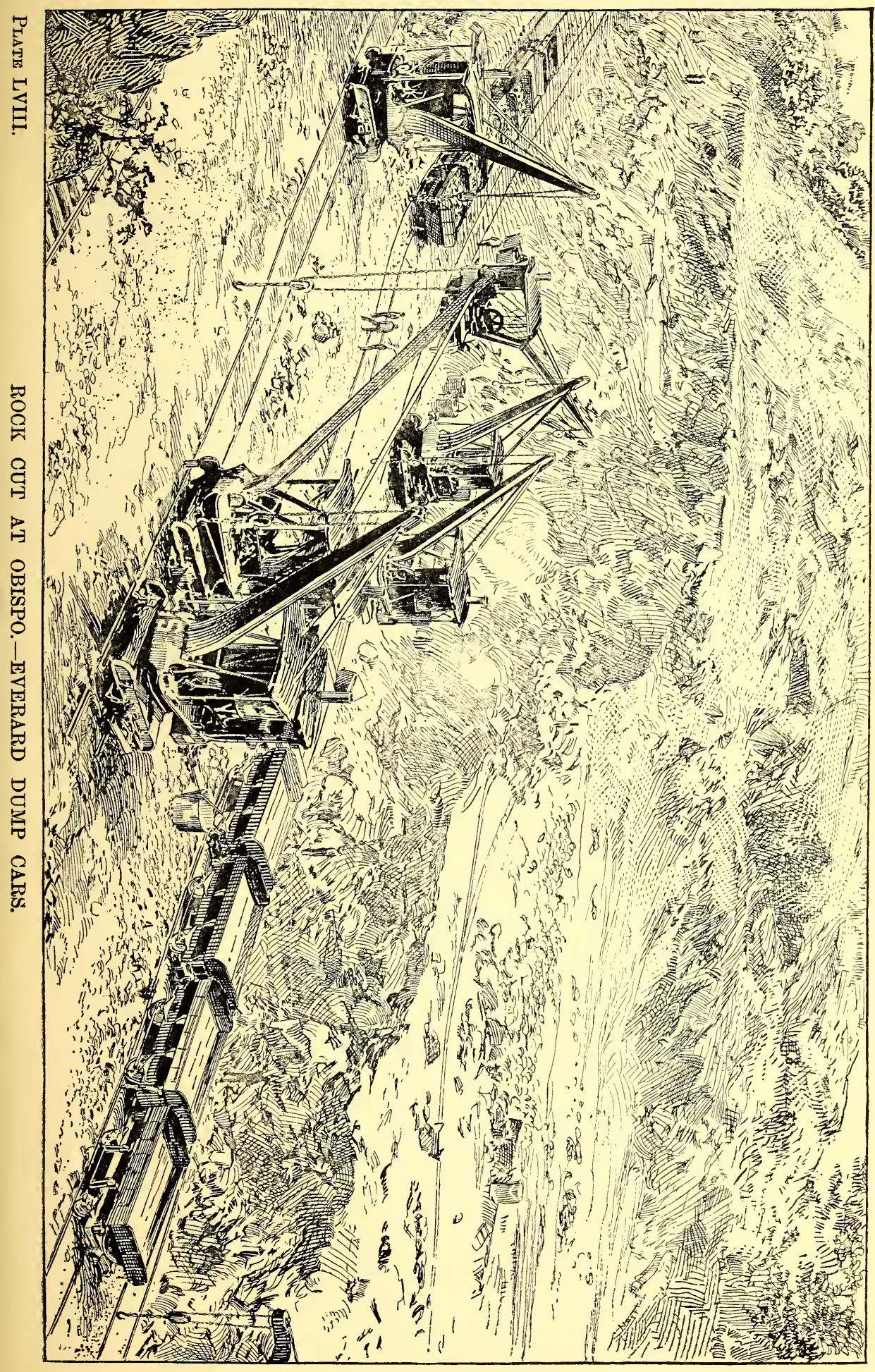



of earth, 10 tons. When the car is evenly loaded the center of gravity is well preserved and the car may be easily dumped by the aid of two men. At each end of the body is a hemispherical cam, resting vertically upon a track supported upon the frame of the car, so that the body is allowed to move through an are of 45 degrees. One serious objection which may be easily remedied is the use of a buffer in one continuous piece, running underneath the car and connected by a lug with a spiral spring. If cars are run into, the concussion causes the buffer to retreat, and the motion is not sufficiently counteracted by the spring, it being too light, and consequently the buffer from the shock is knocked out of place, retreats to rear, and striking the buffer of the second car a buckling occurs.

I would suggest that this spring be doubled in strength and the buffer then would be enabled to stand the shock of adjoining cars. The handles used to keep the car in a horizontal position are much too long and often strike against the dumps along the line when not leveled off. Shorter handles would be more effective, as in a car upset on the dump no more leverage is gained in using a long handle to restore it to a normal position than by using a short handle, which is more rigid and admits of no lateral pull.

I have not attempted to explain in detail the relative merits of the different machines, but have only described the plant doing the most effective work, and later in the year I hope to present a paper on the "Dredging Appliances" in use on the Panama Line, with detail drawings of each and a history of their work.

The same machinery in use on the Panama Line, when worked by intelligent Americans and operated by American contractors, would accomplish a larger ratio of work; but this will never occur, as the climate alone forbids the economical employment of any number of skilled white men.

In connection with the paper on the "Plant and Machinery on the Panama Canal," it may be interesting to engineers to be informed how much work has been accomplished by the use of this plant on the canal, and how much work remains to be doze, and the probable cost of that work. 
The first estimate of the work to complete a sea-level canal, stated at the "International Congress" at Paris in 1879, was a cube of 46000000 meters, which was increased later to 75000000 cubic meters and 105000000 cubic meters; while in 1885 this estimate was still further increased to 151000000 cubic meters, of which 20000000 cubic meters was for "derivations."

The official reports state that up to June, 1888, the Canal Company had expended $\$ 177910000$ and had accomplished 49000000 cubic meters, showing an expenditure of $\$ 362$ per meter. This work has been accomplished under conditions much more favorable than will be encountered in the future, when, as the cuts are deepened and the material becomes harder, the length of haul and time of handling willincrease the cost of the work materially.

The total par value of the several loans to June, 1888, is $\$ 351150900$, the loans having first been taken in 1882 at a discount of $12 \frac{1}{2}$ per cent., bearing interest at 5 per cent., while the last loan was floated at par, bearing 3 per cent. interest, and was finally taken up at 56 per cent. discount.

The interest and fixed charges on this amount expended is more than $\$ 20000000$ per annum.

An accurate idea can be gained by looking at the profile on Plate LIX.

This profile was issued by the Canal Company in Paris in January, 1888 , for the purpose of infusing new interest amongst financiers in the adoption of the lock system. The showing of the profile and the comparison between work to be done and work already accomplished was so dangerous to the Canal Company that the issue of this profile was suppressed.

The first announcement made by the Canal Company that 40000000 cubic meters remained to be extracted under the lock system was still further reduced in the publication on May $2 d$ in the "Bulletin du Canal Interoceanique," that only 32132244 cubic meters remained to be extracted.

A careful calculation by scale, as shown on the profile of the amount of excavation for the lock canal between kilometers 18 and 68 , gives 37250627 cubic yards. These estimates are made by taking the center heights and slopes at $1 \frac{1}{2}$ to 1 .

In a number of cases the center of the canal has been excavated deeper than the sides, so on this profile, which was taken along the cen- 


$$
\Rightarrow
$$




ter line, we do not get the average cutting, bu't a height much more favorable to the canal than against it. The slopes in many instances have been carried further back at an angle of 2 to 1 on account of the sliding tendency of the soil.

This estimate does not include the amount of excavation necessary for the "derivation" on either side of the canal, as while the location of the canal itself is made with a view to the most advantageous operation, it is not always possible to find equally favorable locations for the parallel channels.

In places the amount of excavation in the derivation channel exceeds the cube of the canal. Again, this aggregate amount does not include the excavation in deepening the canal from 15 to 27 feet between kilometers 1 to 18 , and the escavation from kilometer 68 to 74 , which is of the most difficult nature, as coral rock has been met with all along this section.

It is safe to estimate that the excavation necessary to complete the lock canal and derivations will exceed 60000000 cubic meters, and the cost of handling $\$ 250$ per cubic meter, requiring $\$ 150000000$ in cash outlay.

The interest and fixed charges on work already accomplished for the next four years, the earliest possible time at which it might be completed, will be $\$ 80000000$.

From past experience at least $\$ 2.50$ for $\$ 1$ will have to be paid for the negotiation of the new securities. This will necessitate obligations to be issued of $\$ 575000000$, which, in addition to the $\$ 351000000$ debt already incurred, would give a total of $\$ 926000000$ as the cost of the completed canal.

The tonnage of the world availing itself of the use of the canal in 1892 will not be over 5000000 to 6000000 , which, if taxed as high as $\$ 3$ per ton, would only yield $\$ 18000000$.

Then the cost of operating a lock canal with an artificial water supply will at least require the expenditure of $\$ 3000000$ per year.

Even at this high rate of tax on tonnage, the canal would only yield a dividend of a little over two per cent. per year.

The future work and completion of the Panama project is purely theoretical, and problematical in the extreme, standing, as it does today, on the verge of a financial crisis, which may be hastened at any moment by De Lesseps' death, as no man has succeeded in raising such 
sums of money for an enterprise which at the start was so misjudged and underestimated.

At this late date problems relating to the Chagres River control are still unsolved, and the blunders of the past will surely creep in during future work.

Now, the company's rate of excavation, even with the help of the large figures from the Colon-Gatun section, has not averaged 1000 . 000 cubic meters per month, the past two years through. At the best rate of progress, therefore, and with the most liberal allowances, there is work enough to consume four years, and that would involve the disbursement of something like $\$ 80000000$ for interest and sinking fund of the debt and expenses of administration, without counting a dollar for work or material on the canal itself.

Though the work accomplished thus far has been the easiest that the line presents, still, more than one contractor has succumbed before the difficulties of the Culebra. Some of the richest and most experienced firms of Europe have declared the tasks of that portion of the line beyond their power to accomplish, and have abandoned their contracts. Those tasks have not been lightened nor the difficulties lessened by the operations hitherto effected. The laborers are not more numerous nor more efficient than they were when Señor Tanco Armero declared that the results of their work convinced him that there had never been more than 5000 men employed, though the company claimed to have 15000 .

Again, the water for the supply of the lock system, so far as is known, is to be furnished from the Chagres River. In the dry season the flow of the Chagres is at the rate of 10 cubic meters per second, of the Obispo 1 cubic meter, and of the Rio Grande 0.4 cubic meters. The three streams would therefore supply some 259977600 gallons per day. The capacity of each of the locks is 40000 cubic meters, and each vessel crossing the summit level will require the two locks to be emptied once, using something like 80000 cubic meters of water. The Panama Company claims a tonnage of 10000000 per year, or 28000 tons per day, representing twenty vessels of 1400 tons each, although this seems to us a most exaggerated estimate. The water required for their transit would be 322400000 gallons per day. The evaporation and filtration, estimated at one per cent. per day, would entail a loss of something like 47300000 gallons, making the daily requirement amount to 369700000 gallons. The supply is 259977600 , and the shortage on this basis 109765260 gallons. 


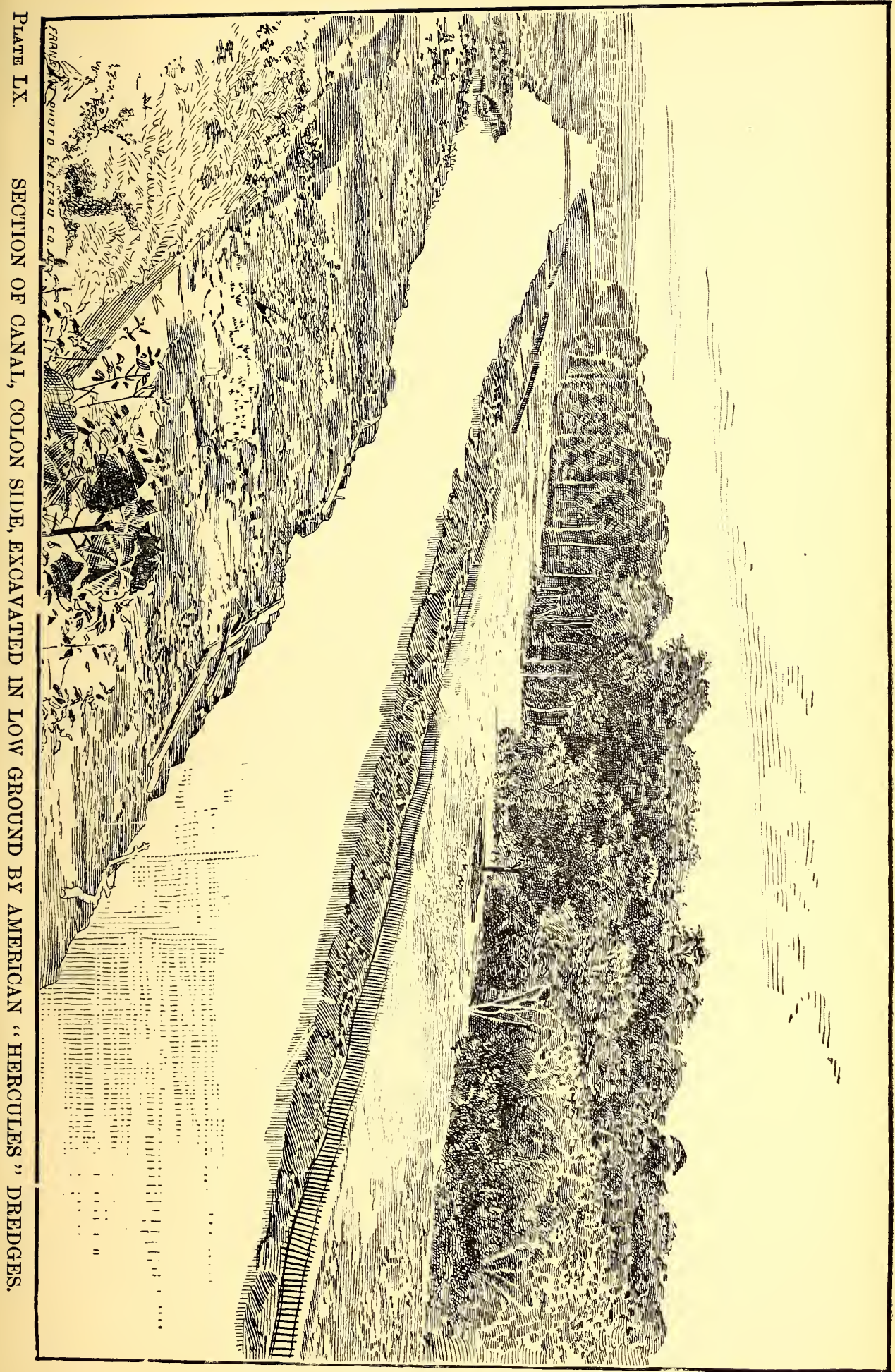



In the rainy months the opposite conditions will prevail.

The Gamboa Dam, as originally proposed by French engineers, was to be 975 feet long on the kase and 113 feet high, with outside slopes of 4 to 1 , and was to consist of 10000000 cubic meters of rock and clay. The site was to ke dredged some 60 feet to a solid foundation. These plans have been changed on account of the adoption of the lock system and the dam will only be carried to a height of 95 feet. Its total contents are 3000000 cubic meters, and already about 30000 cubic meters have been deposited on the flanks of the hills at the two ends. No excavation has been attempted to gain a solid foundation, the theory being that on account of the immense weight of the deposited material it will gradually settle to a compact foundation. The original plans contemplated a receiving reservoir holding 1215000000 cubic meters, which would be adequate to. hold the waters of a six-day flood, the longest continuous rain-fall of the past ten years. By the new plan the reservoir will only hold 160000000 cubic meters, and the maximum discharge of the Chagres will fill it in twenty-seven hours if empty; but in the rainy season the dam will be well filled, and in case of an extended rain-fall the dam will only be available for storing water for pumping purposes for filling of the upper summit level, while the unruly Chagres will still be uncontrolled.

From kilometers 45 to 23 the adjoining country is drained by the Chagres River, and in the event of a six-days' flood its rise becomes enormous. In some cases the Chagres flowing in its original channel approaches within a few feet of the canal, when it is suddenly turned into a derivation channel, in some cases at right angles to its former course. Unless walls of masonry are constructed to protect these banks from the eddying effects of the stream, the Chagres will break through these mud banks and destroy the canal.

At many points between Gamboa and Colon, during the rainy season, the bed of the canal is lower than the Chagres, and is overflowed by it, completely stopping work on those sections. The sudden breaks in the surface shown on the profile are all crossings of the Chagres. Hence the small results shown for seven years' operations in this portion of the line; and it is apparent that until the deviations for the river on both sides of the canal are adequate to control the maximum drainage the work on these lower sections cannot make substantial progress. One of the objects of the construction of the Gamboa dam is to control 
the flow of the Chagres, so that this part of the canal may be protected from its floods; but the cube of the deviations which have so far been made or proposed is only about one-quarter of the capacity required by the river in the height of the rainy season, the constructing engineers having adopted the view that the river will gradually enlarge the capacity of the deviations to its own requirements.

In April Jast I steamed from Colon up to kilometer 15, this length of canal being located in flat and marshy land, and the work has been accomplished by the Hercules dredges in discharging the material on either bank; but this work can only be carried on in the upper levels at enormous expense and trouble, as is shown by the lack of progress beyond kilometer 15 on the profile.

This open section of the Panama Canal (Plate LX) has been the subject of much comment and congratulation on the part of interested persons, both here and in France. The contractors have used it to show the efficiency of their work, and the Canal Company's supporters have printed pictures of it, and elaborated its advantages for developing local trade and for use in transporting material and supplies to the works. In view of the uncontrolled flow of the Chagres, and the liability of this lower portion of the canal to damage from caving and silting, the policy of dredging it years before the whole can be completed, so as to render this part of use, would seem, to put it mildly, very questionable. The monthly cube of extraction reported at Paris has undoubtedly benefited largely by it, and pictures and descriptions of "sixteen finished kilometers of sea-level canal" may have been of value at certain critical moments; but if the "open section" is ever to form part of an interoceanic canal it will probably have to be all dredged out again some years hence, and the interest on the money paid for it would make a comfortable sum, which has been completely thrown away. It will be apparent to engineers that with the rest of the work in the state shown, this section should still be lying untouched, if the work as a whole was to be prosecuted economically, without regard to the necessity of impressing the gullible and ignorant.

The Great Culebra Cut (Plate LXI). - This view, taken in April, 1888, shows the summit of the canal in the center of the Culebra cut, at kilometer 54, and exhibits the maximum amount of excavation done at any point on the line. The depth from the original surface to the bed of 


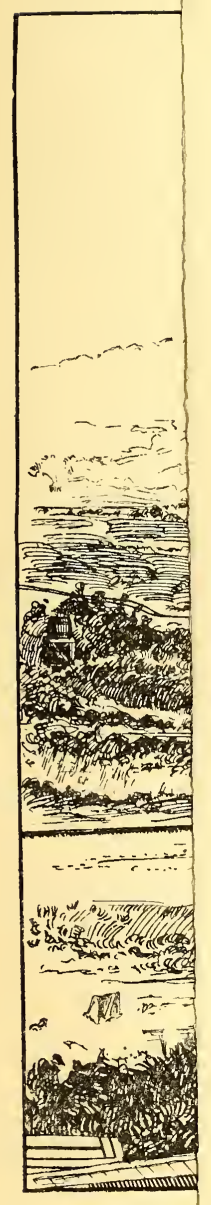

Plate LX 



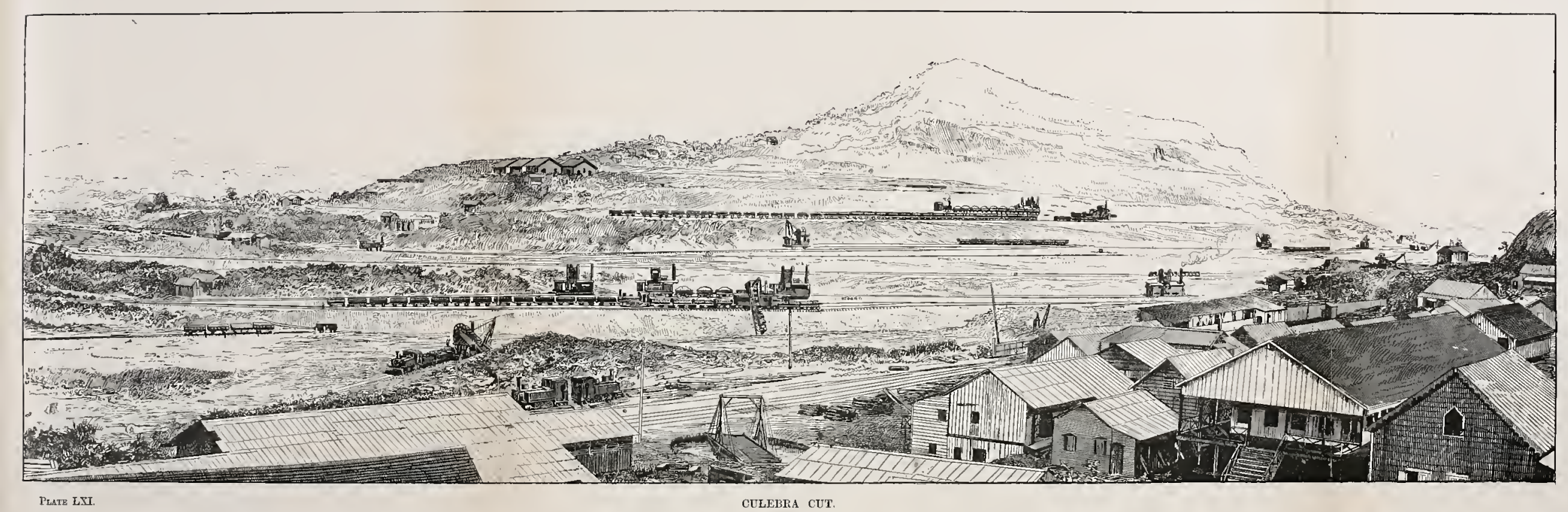





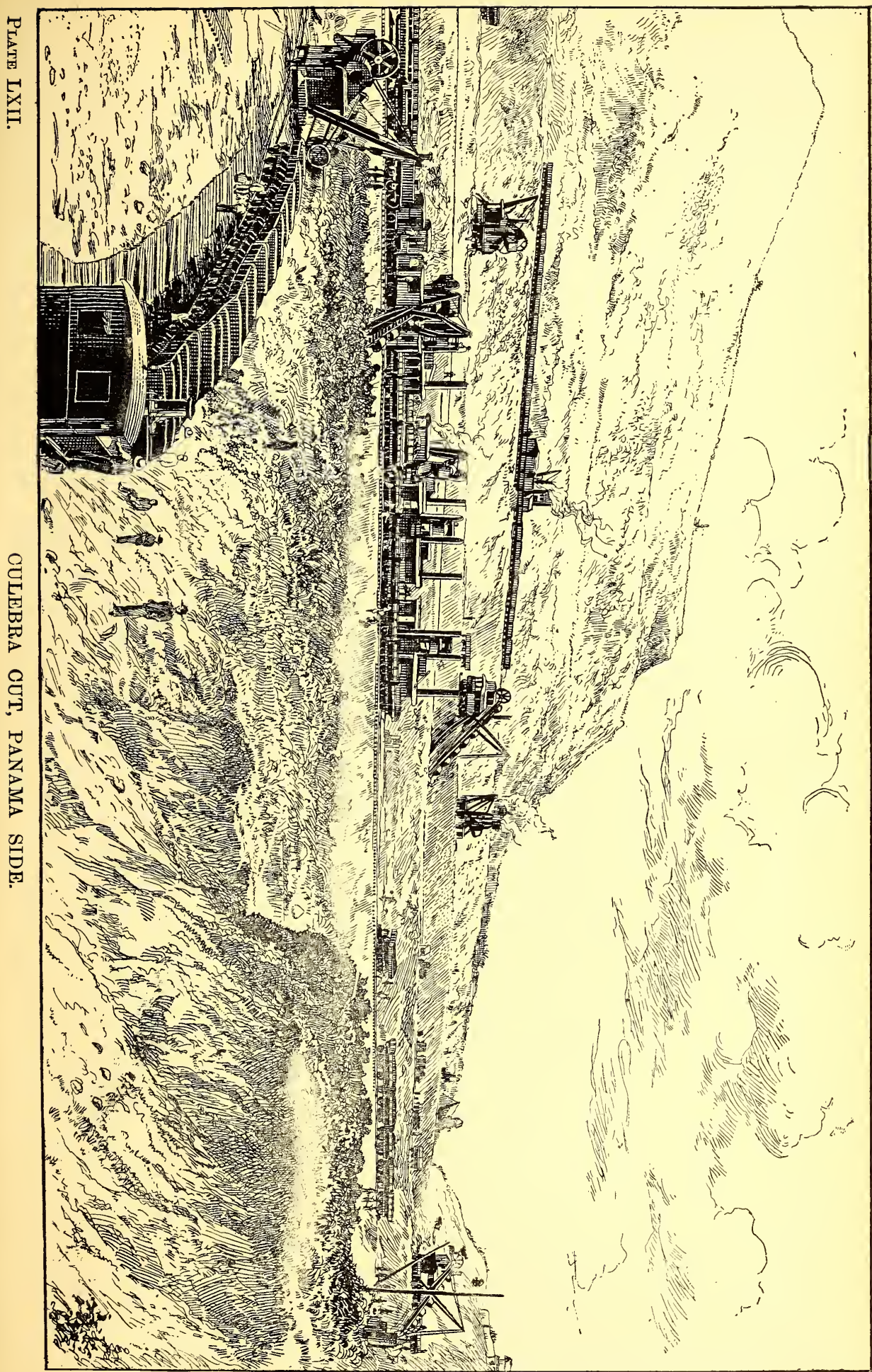




the sea-level canal at this point was 354 feet. About 93 feet have been taken out, leaving 111 feet to be excavated to the bed of the upper lock-level, as shown in the profile, or 261 feet to the bed of the sea-level canal, through a length of 3300 feet. The abandonment of the upper lock would add 30 feet in depth for a distance of $3 \frac{1}{8}$ miles; making the maximum cut 141 feet to the bed of the next lock-level, and the excavation for the lock canal through the central mass between Paraiso and Haut Obispo, . a distance of $5 \frac{1}{8}$ miles, would vary from 90 to 120 feet, apart from the 3300 feet of the maximum cut. The profile shows at a glance that in general very little progress has been made in these difficult sections.

The surface width for a depth of 204 feet from the original surface to the bed of the upper lock-level, at a slope of $1 \frac{1}{2}$ to 1 , would be 750 feet. At this slope, which is the one now adopted, great difficulty is experienced from land slides, one of which may be seen in the upper center of the picture, on the face of the mountain. In consequence of this caving tendency the terraces have already been forced backward and upward on the mountain side, which has necessitated the readjustment of the lower terraces, and this characteristic will render further widening necessary as the cut is deepened.

In the earlier excavation it was possible to dump the material on both flanks of the mountain, upon the same level, and about half a mile away; but on the lower terraces the haul is largely increased, the dumping grounds being outside the cutting, on the extreme right and left; and requiring long trestles, 50 and 60 feet high, reaching out over the adjacent swamps that are being rapidly filled up. As the excavation descends the length of haul from the center of the works increases in a heavy ratio.

On the extreme left of the picture, in the lowest cutting in the foreground, the depth remaining to be excavated is over 100 feet to the lock level, or 250 to the sea level. In proportion with the deepening of the cut the hauling engines must overcome a heavy grade over an increasing vertical distance, and as the dumping grounds fill up, new ones must be found farther away.

It will be apparent that the excavation on the upper levels was accomplished with a minimum of labor and expense, and that as the cut descends the work will entail a rapidly increasing consumption of time and money in its execution.

The excavators chiefly employed here are of the endless-chain-ofbuckets type, one or two of which are seen at work in the picture. 
These were satisfactory in working upon the sandy material of the Isthmus of Suez, but they prove much less effective when attacking the hard pan and stiff clay of the Culebra. In connection with this plant are used Belgian 36-ton locomotives, and the Everard iron dump cars, as seen upon the railway tracks in the picture, which was taken while work was going on at the usual rate, as we understand, and will enable those familiar with public works to appreciate how likely it is that the remaining work will be completed by 1890 or 1891, when this is what has been accomplished in the seven years, 1891-88.

Plates LXII and LXIII are from photographs of other portions of the Culebra Cut.

The Emperador Cut. (Plates LXIV, LXV).-This view, taken in 1888, shows the canal line at kilometer 50.500, in the Emperador section, at the other end from Culebra of the great central level. The view is taken looking toward the Atlantic through the Valley of Emperador, in the direction of Haut Obispo. On the extreme left may be seen the dumping grounds for the excavations, reached by rail, and already used to a large extent. In the left center are the houses and shops of the contractors and the huts for the laborers.

The work done thus far amounts to little more than the removal of the surface earth. The excavation still required along this immediate front for two miles is 60 feet deep to the lock level, over 210 feet to the sea level. A distance of a mile and a half, to kilometer 53, requires from 90 to 120 feet of excavation to the lock level, or 240 to 270 to the sea level, while at kilometer 47 the excavation is 15 feet below the level of Lock No. 4, necessitating embankments, as is also the case at Lock No. 3, at Gamboa.

The deviation of the Rio Grande is unfinished, rendering progress exceedingly difficult in the rainy season, as the river overflows the works. There was erected here a through truss iron bridge to carry the Rio Grande over the canal and unite it with the Rio Obispo on the opposite bank, but on account of the change from the sea level to the lock system orders were sent from Paris in April to have the bridge taken down. This has been done, and it is stated at an expense greater than the original cost of the erection, and the parts are stored away to await further developments.

All the views given with this paper are reproductions of photographs actually taken upon the ground. 


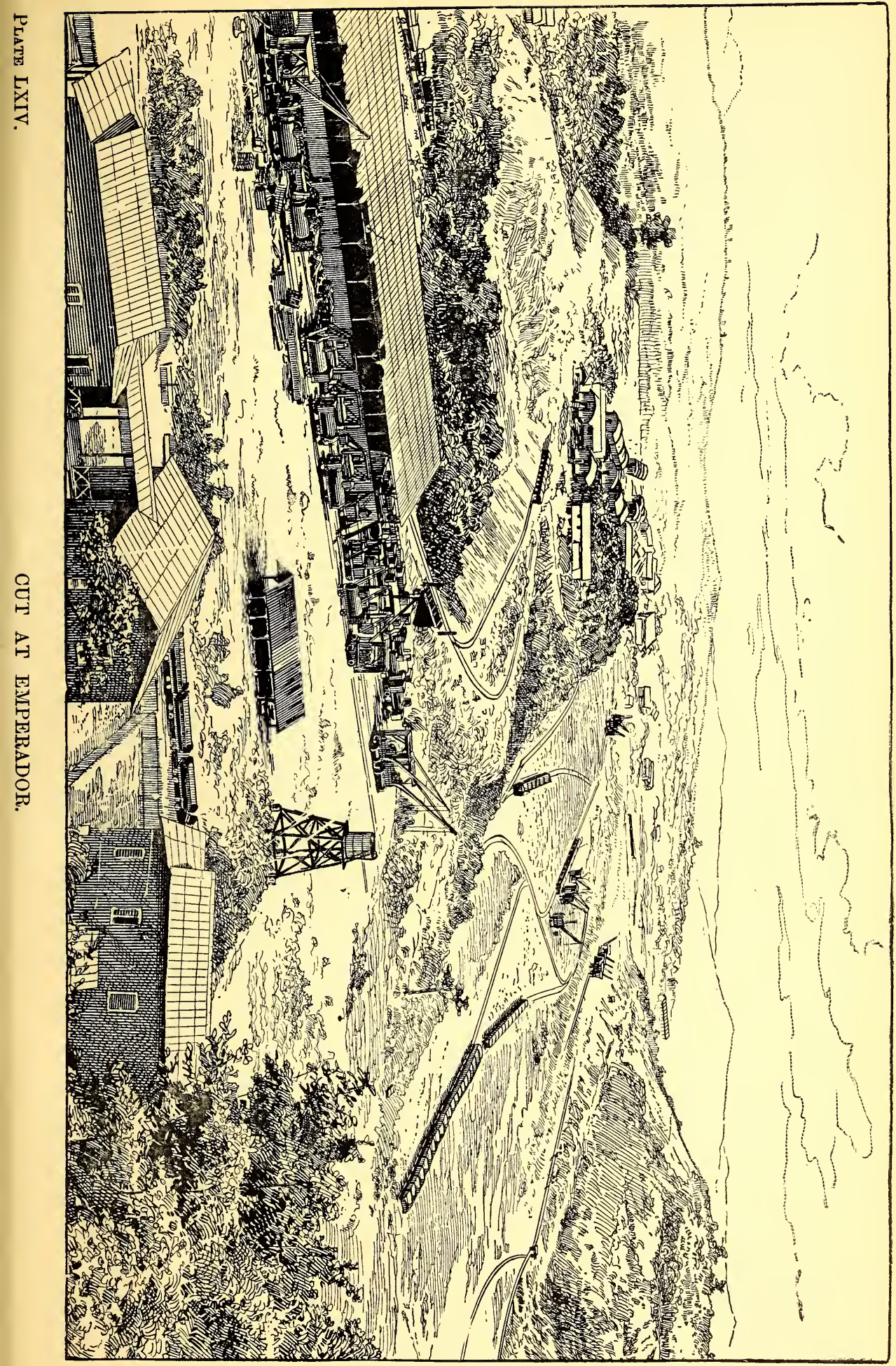





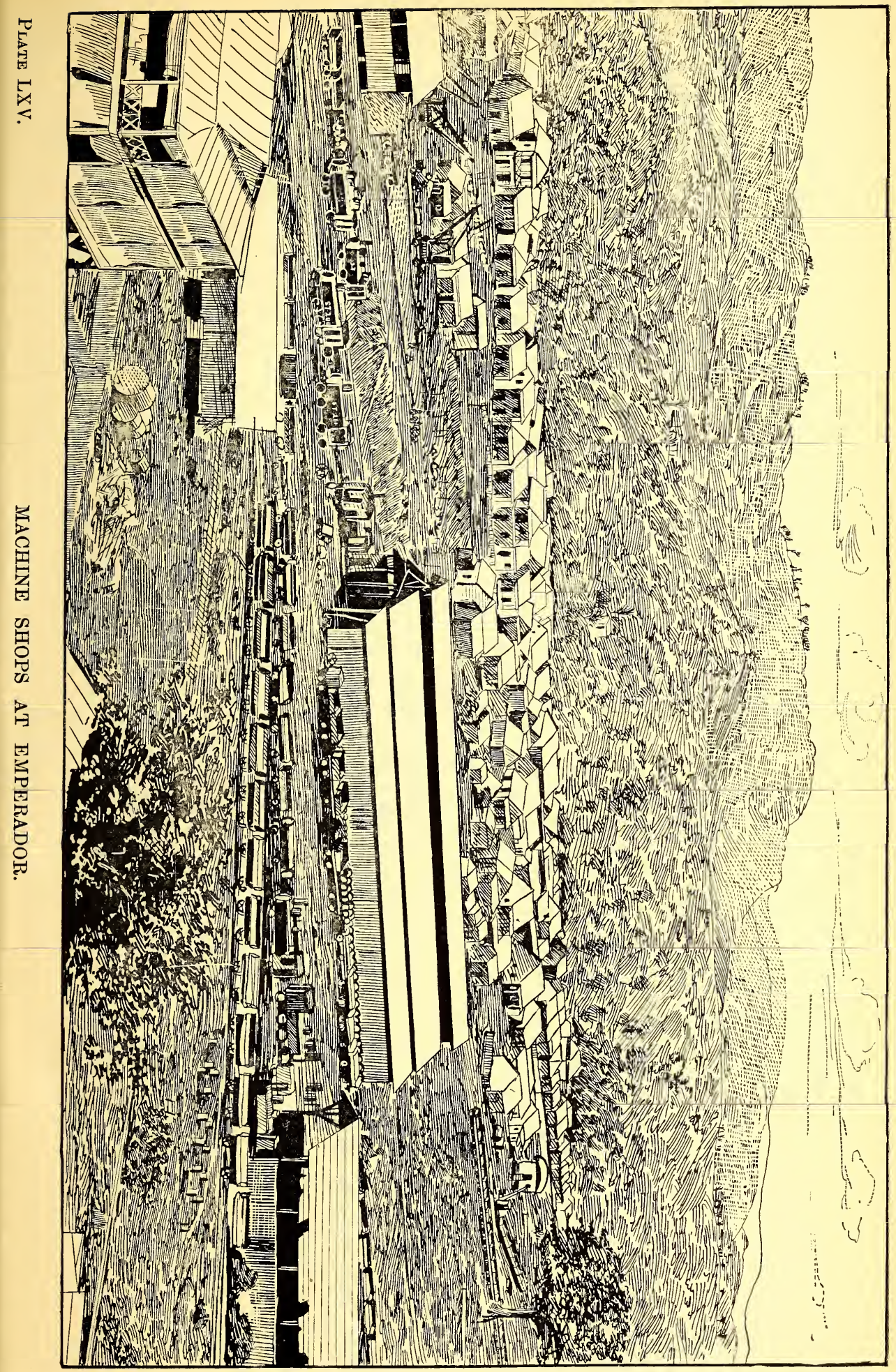





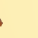








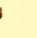





o 





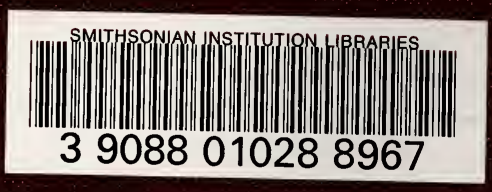

